\title{
Relative influence of variables at multiple spatial scales on stream macroinvertebrates in the Northern Lakes and Forest ecoregion, U.S.A.
}

\author{
BRIAN M. WEIGEL*, LIZHU WANG*, PAUL W. RASMUSSEN*, JASON T. BUTCHER ${ }^{\dagger}$, PAUL $^{*}$ \\ M. STEWART ${ }^{\ddagger}$, THOMAS P. SIMON ${ }^{\S}$ AND MICHAEL J. WILEY ${ }^{\bullet}$ \\ *Wisconsin Department of Natural Resources, Bureau of Integrated Science Services, Monona, WI, U.S.A. \\ tU.S. Forest Service, Superior National Forest, Duluth, MN, U.S.A. \\ $\ddagger$ Troy State University, Department of Biological and Environmental Sciences, Troy, AL, U.S.A. \\ §U.S. Fish and Wildlife Service, Bloomington, IN, U.S.A. \\ -University of Michigan, School of Natural Resources and Environment, Ann Arbor, MI, U.S.A.
}

\section{SUMMARY}

1. We used 94 sites within the Northern Lakes and Forests ecoregion spanning Minnesota, Wisconsin and Michigan to identify environmental variables at the catchment, reach and riparian scales that influence stream macroinvertebrates. Redundancy analyses (RDA) found significantly influential variables within each scale and compared their relative importance in structuring macroinvertebrate assemblages.

2. Environmental variables included landcover, geology and groundwater delivery estimates at the catchment scale, water chemistry, channel morphology and stream habitat at the reach scale, and landcover influences at three distances perpendicular to the stream at the riparian scale.

Macroinvertebrate responses were characterised with 22 assemblage attributes, and the relative abundance and presence/absence of 66 taxa.

3. Each scale defined macroinvertebrates along an erosional to depositional gradient. Wisconsin's macroinvertebrate index of biotic integrity, Ephemeroptera-Plecoptera-Trichoptera taxa and erosional taxa corresponded with forest streams, whereas organic pollution tolerant, Chironomidae and depositional taxa corresponded with wetland streams. Reach scale analyses defined the gradient similarly as dissolved oxygen and wide, shallow channels (erosional) opposed instream macrophytes and pool habitats (depositional). Riparian forests within $30 \mathrm{~m}$ of the stream coincided with an erosional assemblage and biotic integrity.

4. Next, we combined all significant environmental variables across scales to compare the relative influence of each spatial scale on macroinvertebrates. Partial RDA procedures described how much of the explained variance was attributable to each spatial scale and each interrelated scale combination.

5. Our results appeared consistent with the concept of hierarchical functioning of scale in which large-scale variables restrict the potential for macroinvertebrate traits or taxa at smaller spatial scales. Catchment and reach variables were equally influential in defining assemblage attributes, whereas the reach scale was more influential in determining relative abundance and presence/absence.

Correspondence: B. M. Weigel, Wisconsin Department of Natural Resources, Bureau of Integrated Science Services, 1350 Femrite Dr., Monona, WI 53716, U.S.A. E-mail: brian.weigel@dnr.state.wi.us 
6. Ultimately, comprehending the relative influence of catchment and reach scale properties in structuring stream biota will assist prioritising the scale at which to rehabilitate, manage and derive policies for stream ecosystem integrity.

Keywords: biomonitoring, index of biotic integrity, landcover, multivariate, redundancy analysis

\section{Introduction}

Environmental variables among multiple spatial scales control physicochemical and biological processes in streams (Hynes, 1970, 1975). Variables at regional or catchment scales can affect streams directly, or indirectly by constraining other environmental variables at lower scales (Frissell et al., 1986; Allan, Erickson \& Fay, 1997; Poff, 1997). Understanding the relative influence of environmental variables at catchment and local spatial scales is an important step towards improved restoration, management and assessment of aquatic resources (Richards, Host \& Arthur, 1993; Johnson \& Gage, 1997). Knowing which and how different spatial scale factors integratively affect stream communities also increases our ability to detect anthropogenic influences, identify biological response signatures to human-induced stress and ultimately improve river health (Norris \& Thoms, 1999; Weigel, 2003).

Several researchers have studied the relative influence of environmental variables at different scales on instream habitat, water chemistry and biota but their results tend to depend largely upon the predictor and response variables investigated and the environmental setting (Allan \& Johnson, 1997; Townsend et al., 1997). Most of these comparisons were conducted in largely agricultural catchments (e.g. Hunsaker \& Levine, 1995; Roth, Allan \& Erickson, 1996; Wang et al., 1997). In contrast, this study provides information on the influences of different spatial scale variables on biological communities in a least-influenced, non-agricultural region.

Stream health assessment often requires knowledge of the natural distribution of the indicator biological communities so that targeted stream health can be evaluated relative to natural reference conditions. Stream macroinvertebrate assemblages have a broad distribution and reflect the environment in which they live, and thus, they are commonly used as indicators of stream health. Macroinvertebrates are exceptional signals of environmental conditions because they respond integratively to influences at multiple spatial scales through properties of both physical habitat and water chemistry (Cummins, 1974; Vannote et al., 1980; Resh \& Rosenberg, 1984). Macroinvertebrate assemblage structure, life history traits and taxon presence/ absence react predictably to environmental alterations, indicating stream integrity (Barbour et al., 1996; Wallace, Grubaugh \& Whiles, 1996; Hawkins et al., 1997; Karr \& Chu, 1999). Understanding how natural environmental factors influence stream macroinvertebrates will help account for natural variability in ecological modelling, and thus, enhance our bioassessment abilities.

Our first study objective was to identify key environmental variables within the catchment, reach and riparian scales that affect stream macroinvertebrate assemblage attributes, relative abundance and taxa presence/absence. Our second objective was to evaluate the relative influence of environmental variables from different spatial scales in determining macroinvertebrate assemblages. Ultimately, comprehending the relative influence of catchment-, reachand riparian-scale properties in structuring stream biota will assist prioritising the scale at which to rehabilitate, manage and derive policies for stream ecosystem integrity.

\section{Methods}

Study area

Our study area spanned the $180500 \mathrm{~km}^{2}$ Northern Lakes and Forests ecoregion in the upper Midwestern U.S.A. (Omernik \& Gallant, 1988). Various sized lakes, wetlands and streams are interspersed within immense coniferous and northern hardwood forests that cover most of the ecoregion. Streams commonly originate in lakes or wetlands and are characteristically brownish from dissolved organic material. Timber harvesting and recreational development are among the most influential human activities in this area. Soil fertility and growing season length limit agriculture. A previous stream macroinvertebrate study indicated that most streams in this region were 
relatively unimpacted, although some streams in catchments with low intensity deforestation or agriculture showed impact (Weigel, 2003).

Twenty-three sites in Minnesota, 37 sites in Wisconsin and 34 sites in Michigan represented inherent environmental variability and human influences throughout the ecoregion (Fig. 1). The 94 sites were randomly selected according to the U.S. Environmental Protection Agency's (U.S. EPA) Environmental Monitoring and Assessment Program (EMAP) (Overton, White \& Stevens, 1990; Stevens \& Olsen, 1999).

\section{Catchment scale assessment}

Catchment characteristics including location, climate, landcover, surficial geology, bedrock geology and groundwater delivery potential summarised environmental information at the catchment scale (Table 1). The downstream end of the sampling site was georeferenced. Mean number of growing degree days and precipitation from the nearest weather station were obtained online from Oregon Climate Service,
Oregon State University. We delineated catchment boundaries upstream of the sampling sites using U.S. Geological Survey 7.5 quadrangle maps and ARC/ INFO software (ESRI, 1999). Catchment boundaries overlaid upon digital landcover maps $\left(900 \mathrm{~m}^{2}\right.$ minimum map unit) facilitated quantifying catchment landcover proportions. We used Anderson et al. (1976) level 1 landcover classifications to standardise data resolution and classification among the three states. Using the same overlay procedures, we used the digital catchment boundaries to calculate proportions of catchment surficial geology types from digital Quaternary geology maps and bedrock geology from digital bedrock geology maps. Raster modelling of Darcy's law estimated potential groundwater input to streams: groundwater $=$ hydraulic conductivity $\times$ hydraulic slope (Wiley, Kohler \& Seelbach, 1997). The potential groundwater delivery rates were estimated for $2-\mathrm{km}$ radius around the site and for the entire catchment, assuming no bedrock was fractured and then assuming all bedrock was fractured, to obtain a minimum and maximum estimate (Baker, Wiley \& Seelbach, 2001).

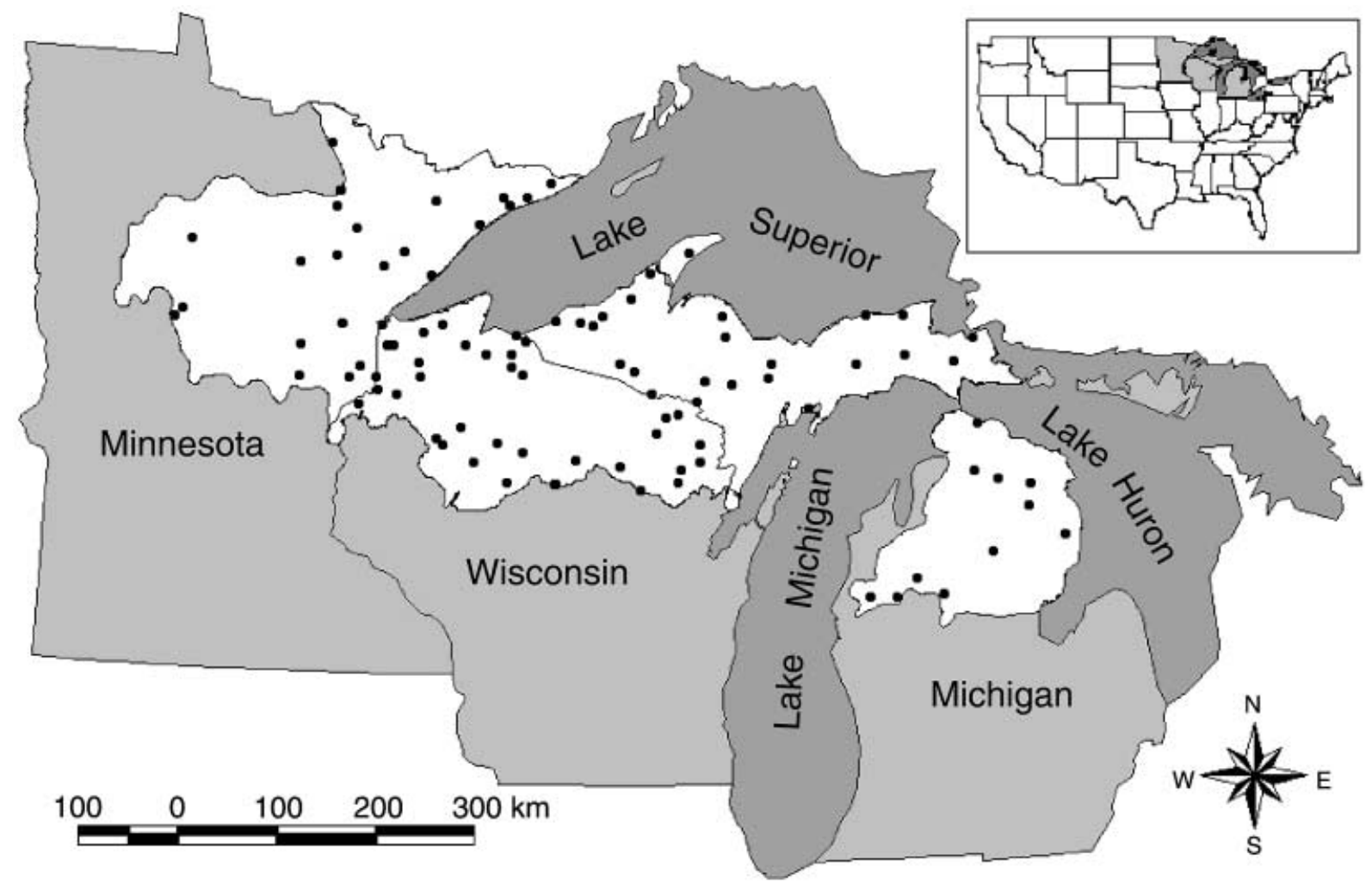

Fig. 1 Upper mid-west with study sites depicted in the Northern Lakes and Forests ecoregion. 
Table 1 Explanation of environmental variables among multiple spatial scales

\begin{tabular}{|c|c|}
\hline Variable & Definition \\
\hline \multicolumn{2}{|l|}{ Catchment scale } \\
\hline \multicolumn{2}{|c|}{ Location, climate and groundwater characteristics } \\
\hline Latitude & Latitude at downstream end of sampling site; measured by GPS with post processing \\
\hline Longitude & Longitude at downstream end of sampling site; measured by GPS with post processing \\
\hline Altitude & Altitude at downstream end of sampling site; measured from $1: 24000$ quadrangle map \\
\hline Catchment area & Catchment area upstream of sampling site; measured with GIS using digital $1: 24000$ maps \\
\hline Slope & Slope of catchment upstream of site; measured with GIS using digital elevation map \\
\hline GDD & Growing degree days; reported from nearest weather station \\
\hline Precip & Annual mean precipitation; reported from nearest weather station \\
\hline DARSITMX & $\begin{array}{l}\text { Potential groundwater discharge estimated with Darcy's law for 2-km radius around the site, } \\
\text { intersected by catchment boundaries. Assumed all bedrock was fractured }\end{array}$ \\
\hline DARSITMI & $\begin{array}{l}\text { Potential groundwater discharge estimated with Darcy's law for 2-km radius around the site, } \\
\text { intersected by catchment boundaries. Assumed no bedrock was fractured }\end{array}$ \\
\hline DARSHDMX & $\begin{array}{l}\text { Potential groundwater discharge estimated with Darcy's law for entire catchment. Assumed } \\
\text { all bedrock was fractured }\end{array}$ \\
\hline DARSHDMI & $\begin{array}{l}\text { Potential groundwater discharge estimated with Darcy's law for entire catchment. Assumed } \\
\text { no bedrock was fractured }\end{array}$ \\
\hline \multicolumn{2}{|c|}{ Landcover proportions upstream of sampling site } \\
\hline Agriculture & Uplands cultivated for crops \\
\hline Forest & Uplands with crown closure $>67 \%$ \\
\hline Grass & Uplands with idle and prairie grasses; pasture; timothy or rye \\
\hline Open water & Lake or river area without vegetation present \\
\hline Urban & Impervious surfaces of man-made materials; golf courses \\
\hline Wetland & Persistently wet meadow, lowland shrub or lowland forest with $<10 \%$ canopy closure \\
\hline Other & Coverages not included in the aforementioned categories \\
\hline \multicolumn{2}{|c|}{ Surficial geology proportions upstream of sampling site } \\
\hline Artificial fill & Artificial fill; measured with GIS using digital Quaternary geology map (QGM) \\
\hline COSTXGT & Coarse-textured glacial till; measured with GIS using QGM \\
\hline MEDTXGT & Medium-textured glacial till; measured with GIS using QGM \\
\hline FNTXTGT & Fine-textured glacial till; measured with GIS using QGM \\
\hline ENMCTXT & End moraines of coarse-textured glacial till; measured with GIS using QGM \\
\hline ENMMTXT & End moraines of medium-textured glacial till; measured with GIS using QGM \\
\hline ENMFTXT & End moraines of fine-textured glacial till; measured with GIS using QGM \\
\hline TDSGTOB & Thin discontinuous glacial till over bedrock; measured with GIS using QGM \\
\hline GLOTWSG & Glacial outwash sand and gravel; measured with GIS using QGM \\
\hline ICOTW & Ice-contact sand and gravel; measured with GIS using QGM \\
\hline LACSNSG & Lacustrine sand and gravel; measured with GIS using QGM \\
\hline LACSNCS & Lacustrine clay and silt; measured with GIS using QGM \\
\hline PEATMUK & Peat and muck; measured with GIS using QGM \\
\hline WATER & Water; measured with GIS using QGM \\
\hline \multicolumn{2}{|c|}{ Bedrock geology proportions in catchment upstream of sampling site } \\
\hline Carbonate & Carbonate bedrock; measured with GIS using bedrock geology map (BGM) \\
\hline Metamor & Igneous/metamorphic bedrock; measured with GIS using BGM \\
\hline Sandstone & Sandstone bedrock; measured with GIS using BGM \\
\hline Volcanic & Volcanic bedrock; measured with GIS using BGM \\
\hline \multicolumn{2}{|l|}{ Reach Scale } \\
\hline \multicolumn{2}{|c|}{ Channel morphology } \\
\hline Channelised & Proportion of station that had been straightened or channelised \\
\hline Sinuosity & Sinuosity within $500 \mathrm{~m}$ of station centre; measured using $1: 24000$ quadrangle map \\
\hline Gradient & Stream reach gradient; measured using $1: 24000$ quadrangle map \\
\hline Dist. Bend & Mean distance between bends; measured distances in the field for entire station \\
\hline Dist. Riff. & Mean distance between riffles; measured distances in the field for entire station \\
\hline Mean pool & Mean length of individual pool habitats; measured distances in the field for entire station \\
\hline Mean riffle & Mean length of individual riffle habitats; measured distances in the field for entire station \\
\hline Mean run & Mean length of individual run habitats; measured distances in the field for entire station \\
\hline
\end{tabular}


1444 B.M. Weigel et al.

Table 1 (Continued)

\begin{tabular}{|c|c|}
\hline Variable & Definition \\
\hline Depth & Mean thalweg depth to the surface of the water; measured at 12 transects \\
\hline Depth CV & Water depth coefficient of variation \\
\hline Bank-full depth & Mean stream depth to the estimated bank-full level; measured at 12 transects \\
\hline Width & Mean width of the wetted portion of the stream; measured at 12 transects \\
\hline Bank-full width & Mean stream width at the estimated bank-full level; measured at 12 transects \\
\hline Width/depth & Mean stream width to depth ratio \\
\hline Width/depth CV & Coefficient of variation for width/depth ratio \\
\hline \multicolumn{2}{|l|}{ Streambed habitat } \\
\hline Bedrock & $\%$ of streambed covered with bedrock (solid slab); estimated at 12 transects \\
\hline Boulder & $\%$ of streambed covered with boulder ( $>24 \mathrm{~cm}$ diameter); estimated at 12 transects \\
\hline Cobble & $\%$ of streambed covered with cobble $(6.5-24 \mathrm{~cm}$ diameter); estimated at 12 transects \\
\hline Gravel & $\%$ of streambed covered with gravel $(0.2-6.4 \mathrm{~cm}$ diameter); estimated at 12 transects \\
\hline Sand & $\%$ of streambed covered with sand $(0.0062-0.19 \mathrm{~cm}$ diameter); estimated at 12 transects \\
\hline Silt & $\%$ of streambed covered with silt $(<0.0062 \mathrm{~cm}$ diameter $)$; estimated at 12 transects \\
\hline Detritus & $\%$ of streambed covered with decaying organic material; estimated at 12 transects \\
\hline Small substrate & Sum proportions of silt, sand and detritus substrates \\
\hline Large substrate & Sum proportions of boulder, cobble and gravel substrates \\
\hline Embeddedness & Degree to which cobble or gravel are surrounded by sand or silt; estimated at 12 transects \\
\hline Embedded CV & Coefficient of variation for embeddedness \\
\hline Sediment depth & Mean depth of fine sediment that comprises the streambed; estimated at 12 transects \\
\hline Sediment CV & Coefficient of variation for sediment depths \\
\hline Algae & $\%$ of streambed substrate covered by algae; estimated at 12 transects \\
\hline Algae frequency & Algae frequency; presence counted at four points on 12 transects \\
\hline Macrophytes & $\%$ of streambed substrate covered by macrophytes; estimated at 12 transects \\
\hline Macrophyte frequency & Macrophyte frequency; presence counted at four points on 12 transects \\
\hline \multicolumn{2}{|l|}{ Instream and bank habitat } \\
\hline Logs & Number of logs in stream per $100 \mathrm{~m}$; counted all logs in site $>1.5 \mathrm{~m}$ long and $>0.1 \mathrm{~m}$ in diameter \\
\hline Woody vegetation & Frequency of woody vegetation overhanging from the bank; counted at 12 transects \\
\hline Grassy vegetation & Frequency of grassy vegetation overhanging from the bank; counted at 12 transects \\
\hline Fish cover & Length of fish cover divided by stream width; averaged over 12 transect measurements \\
\hline Shade & Proportion of stream width that was shaded; estimated at 12 transects \\
\hline Shade frequency & Shade frequency; presence counted at four points on 12 transects \\
\hline Buffer & $\begin{array}{l}\text { Mean distance of undisturbed landcover perpendicular to stream; estimated within } 20 \mathrm{~m} \\
\text { of stream at } 12 \text { transects }\end{array}$ \\
\hline Erosion & Proportion of bank that was actively sloughing into the stream; estimated at 12 transects \\
\hline \multicolumn{2}{|c|}{ Water chemistry; measured immediately prior to physical habitat sampling } \\
\hline DO & Dissolved oxygen $\left(\mathrm{mg} \mathrm{L}^{-1}\right)$ \\
\hline Conductivity & Specific conductance (umhos) \\
\hline Alkalinity & Alkalinity $\left(\mathrm{mg} \mathrm{L}^{-1}\right)$ \\
\hline Hardness & Hardness $\left(\mathrm{mg} \mathrm{L}^{-1}\right)$ \\
\hline $\mathrm{pH}$ & $\mathrm{pH}$ \\
\hline Turbidity & Measure of water clarity (NTU) \\
\hline \multicolumn{2}{|c|}{ Riparian landcover (estimated at 12 transects) } \\
\hline \multicolumn{2}{|c|}{$\begin{array}{l}\text { Landcover proportion abbreviations in tables, figures and text include numerals where: } 1=\text { riparian area } 0-5 \mathrm{~m} \\
\text { of the stream, } 2=\text { riparian area } 0-30 \mathrm{~m} \text { of the stream and } 3=\text { riparian area } 30-100 \mathrm{~m} \text { from the stream }\end{array}$} \\
\hline Forest & Trees $>3$-m-tall dominate \\
\hline Shrub & Shrubs $<3$-m-tall dominate \\
\hline Meadow & Grasses and forbs dominate \\
\hline Wetland & Low-lying area dominated by hydrophytic vegetation \\
\hline Cropland & Cultivated for annual crops or mowed for hay \\
\hline Pasture & Grazed by livestock \\
\hline Developed & Commercial, residential or urban areas \\
\hline Other & Landcover not accounted for with the aforementioned categories \\
\hline Undisturbed & Sum forest, shrub, meadow and wetland landcovers; having relatively natural vegetation \\
\hline Disturbed & Sum cropland, pasture and developed landcovers; having relatively modified vegetation \\
\hline
\end{tabular}




\section{Reach scale habitat assessment}

Stream channel morphology, habitat and water chemistry were assessed either during the summer of 1998 or 1999 for the entire site reach when low stream flow facilitated sampling and when natural and human-induced stresses to biota were likely to occur (Table 1). Sampling reaches were designated as a distance of $40 \times$ the mean stream-site width $(150 \mathrm{~m}$ minimum, $500 \mathrm{~m}$ maximum). We measured the length of individual habitat types (e.g. riffles, pools, runs and bends) and distances between the habitat types. Using the Simonson, Lyons \& Kanehl (1994) 12-transect procedure for assessing habitat condition, we documented bank erosion and the stream width at each transect, and substrate composition, water depth and shading at four evenly-spaced places along each transect. The number of submerged logs that had a diameter $=0.1 \mathrm{~m}$ and length $=1.5 \mathrm{~m}$ were counted. Water chemistry was measured at the sites prior to assessing the habitat. We measured dissolved oxygen and conductivity with a YSI-8510 meter (YSI Incorporated, Yellow Springs, OH, USA), pH with a Oakton pHtestr2 (Oakton Instruments, Vernon Hills, IL, USA), alkalinity with a LaMotte alkalinity (WAT-MP-OR), hardness with a (PHT-DR-LT) test kit (both LaMotte Company, Chestertown, MD, USA) and turbidity with a DRT-15C Portable Turbidity meter (HF Scientific Incorporated, Fort Meyers, FL, USA).

\section{Riparian scale landcover assessment}

We assessed riparian landcover at the 12 habitat assessment transects (Simonson et al., 1994). Landcover proportions were visually estimated at $0-5,0-30$ and $30-100-\mathrm{m}$ zones measured perpendicular from each side of the stream (Table 1). The first seven riparian landcover categories in Table 1 accounted for most cover types, but we included an 'other' category, and summed the undisturbed and disturbed cover types.

\section{Macroinvertebrate assessment}

We used a multihabitat stream reach protocol to sample macroinvertebrates once per site during either the autumn 1998 or 1999. A composite sample represented up to six habitat types within each site. Twenty sampling efforts, where two D-frame kicknet
(600- $\mu \mathrm{m}$-mesh) samples constituted one sampling effort, were divided among the six habitat types: hard bottom (substrate $\geq 1 \mathrm{~mm}$ ), aquatic vegetation, undercut banks, snags, leaf packs and soft bottom (substrate $<1 \mathrm{~mm}$ ). For the first five habitat types, we sampled habitats to represent their proportion of length within the site reach. Habitat types representing $<5 \%$ of the site reach were not sampled. To reduce disproportionate effects of sampling extensive lengths of soft bottom habitats, no effort was given to a stream reach with $<40 \%$ soft bottom habitat, one effort was used if the proportion was $40-55 \%$, and a maximum of two efforts were used if the reach had $>55 \%$. In the field, we preserved macroinvertebrates with $80 \%$ ethanol, and in the lab we randomly selected 300 macroinvertebrates using a grid-pan subsorting procedure. Most individuals were identified to the generic level but Chironomidae (Diptera) were identified to family.

We calculated 22 macroinvertebrate metrics related to assemblage composition, structure and function (Table 2). We used a macroinvertebrate index of biotic integrity (IBI) developed for the Northern Lakes and Forest ecoregion of Wisconsin, but the index should be applicable in neighbouring states within the ecoregion (Weigel, 2003). Its values typically range from 0 to 10 , with values $>8$ indicating that the stream health is similar to that of the least influenced sites within the region. We calculated the mean pollution tolerance value (MPTV); a metric in which a high score typically corresponds with symptoms of organic pollution like low dissolved oxygen levels (Lillie \& Schlesser, 1994). We included species richness and per cent Ephemeroptera-Plecoptera-Trichoptera (EPT) taxa because they are easily calculated, stable among reference sites and they track water quality changes effectively (Wallace et al., 1996; Karr \& Chu, 1999). Proportions of depositional genera and individuals, assigned according to Merritt \& Cummins (1996), were included because these taxa can respond to sedimentation resulting from construction, grazing and row crop agriculture (Richards, Johnson \& Host, 1996; Weigel, Henne \& Martinez-R, 2002). We included the proportions of Chironomidae, Diptera, Amphipoda and Isopoda taxa or individuals to reflect stream integrity (Weigel et al., 2000; Weigel, 2003). We calculated macroinvertebrate feeding ecology metrics as a measure of energy linkages across multiple spatial scales (Cummins, 1974; Wallace \& Webster, 1996). All 
Table 2 Macroinvertebrate assemblage metric descriptions and summary statistics for 94 stream sites. (SD = standard deviation)

\begin{tabular}{|c|c|c|c|c|c|c|}
\hline Metric (abbreviation) & Definition & Mean & $\mathrm{SD}$ & Minimum & Median & Maximum \\
\hline Index of biotic integrity (IBI) & Multimetric stream assessment tool & 7.4 & 2.1 & 0.6 & 7.5 & 10.7 \\
\hline $\begin{array}{l}\text { Mean pollution tolerance } \\
\text { value (MPTV) }\end{array}$ & $\begin{array}{l}\Sigma v_{\mathrm{x}} / \mathrm{R} \text { where } v_{\mathrm{x}}=\text { organic pollution tolerance } \\
\text { value of taxon } \mathrm{x} \text { and } \mathrm{R}=\text { taxa richness }\end{array}$ & 4.3 & 1.1 & 2.0 & 4.2 & 6.8 \\
\hline $\begin{array}{l}\% \text { depositional individuals } \\
\text { (Depo \% I) }\end{array}$ & $\%$ individuals tolerant of depositional substrate & 69.3 & 15.2 & 21.1 & 70.5 & 96.8 \\
\hline $\begin{array}{l}\% \text { depositional genera } \\
\text { (Depo \% G) }\end{array}$ & $\%$ genera tolerant of depositional substrate & 54.9 & 9.0 & 37.5 & 54.4 & 77.8 \\
\hline Species richness (SR) & Total number of taxa & 24.1 & 7.6 & 5.0 & 24.5 & 44.0 \\
\hline $\begin{array}{l}\% \text { Ephemeroptera-Plecoptera- } \\
\text { Trichoptera individuals } \\
(\text { EPT \% I) }\end{array}$ & $\begin{array}{l}\% \text { mayfly, stonefly and caddisfly insect } \\
\text { individuals }\end{array}$ & 33.8 & 18.7 & 0 & 33.5 & 85.8 \\
\hline$\%$ EPT genera $(\mathrm{EPT} \% \mathrm{G})$ & $\%$ mayfly, stonefly and caddisfly insect genera & 46.6 & 15.3 & 0 & 48.5 & 75.0 \\
\hline$\%$ Diptera individuals & $\%$ true fly insect individuals & 46.9 & 18.9 & 13.0 & 45.9 & 93.5 \\
\hline$\%$ Diptera genera & $\%$ true fly insect genera & 22.3 & 7.7 & 7.1 & 20.6 & 50.0 \\
\hline $\begin{array}{l}\% \text { Chironomidae individuals } \\
\text { (Midge } \% \text { I) }\end{array}$ & $\begin{array}{l}\% \text { midge family insect individuals } \\
\text { (Order: Diptera) }\end{array}$ & 39.8 & 18.1 & 4.6 & 37.9 & 90.3 \\
\hline $\begin{array}{l}\% \text { Chironomidae genera } \\
\text { (Midge } \% \mathrm{G} \text { ) }\end{array}$ & $\begin{array}{l}\% \text { midge family insect genera } \\
\text { (Order: Diptera) }\end{array}$ & 4.7 & 2.4 & 2.2 & 4.0 & 20.0 \\
\hline $\begin{array}{l}\% \text { class Amphipoda-Isopoda } \\
\text { individuals (Amp-Iso\% } \% \text { ) }\end{array}$ & $\begin{array}{l}\% \text { side-swimmer and sowbug } \\
\text { individuals }\end{array}$ & 5.8 & 11.0 & 0 & 1.0 & 64.0 \\
\hline$\%$ predator individuals & $\%$ individuals that engulf or pierce animal prey & 10.7 & 9.0 & 1.4 & 8.6 & 68.2 \\
\hline$\%$ predator genera & $\%$ genera that engulf or pierce animal prey & 32.2 & 9.6 & 11.5 & 32.1 & 58.3 \\
\hline$\%$ shredder individuals & $\%$ individuals that shred detritus or vegetation & 3.5 & 3.6 & 0 & 2.4 & 19.3 \\
\hline$\%$ shredder genera & $\%$ genera that shred detritus or vegetation & 9.5 & 6.1 & 0 & 8.3 & 24.0 \\
\hline$\%$ scraper individuals & $\%$ individuals that scrape particles from substrate & 13.1 & 13.5 & 0 & 9.1 & 54.8 \\
\hline$\%$ scraper genera & $\%$ genera that scrape particles from substrate & 16.3 & 9.6 & 0 & 16.7 & 42.9 \\
\hline$\%$ filterer individuals $(\mathrm{Flt} \% \mathrm{I})$ & $\begin{array}{l}\% \text { individuals that filter particles from flowing } \\
\text { water }\end{array}$ & 8.1 & 8.1 & 0 & 6.0 & 35.6 \\
\hline$\%$ filterer genera $(\mathrm{Flt} \% \mathrm{G})$ & $\%$ genera that filter particles from flowing water & 10.5 & 6.0 & 0 & 20.8 & 11.7 \\
\hline$\%$ gatherer individuals & $\%$ individuals that collect particles from substrate & 64.6 & 18.1 & 20.6 & 66.5 & 97.7 \\
\hline$\%$ gatherer genera & $\%$ genera that collect particles from substrate & 30.6 & 8.7 & 11.5 & 29.3 & 60.0 \\
\hline
\end{tabular}

proportion metrics were calculated as per cent individuals and per cent genera.

We categorised macroinvertebrate information into three data sets: macroinvertebrate assemblage attributes, macroinvertebrate relative abundance and taxon presence/absence. For the relative abundance and presence/absence data sets, we only included the 66 taxa that occurred at $\geq 10$ sites. We used three commonly calculated macroinvertebrate data sets to observe which environmental variables were influential repeatedly, suggesting consistency and reliability among results.

\section{Statistical analyses}

Our statistical analyses had three main components. First, we identified key environmental variables within the catchment, reach and riparian scales that affected stream macroinvertebrate attributes and species composition. We had three environmental variable data sets (i.e. catchment, reach and riparian), and three macroinvertebrate data sets (i.e. assemblage attributes, relative abundance, presence/absence). We ran an analysis for each scale and macroinvertebrate data set pair, totalling nine sets of analyses. We performed redundancy analysis (RDA) on each data set pair using the log transformation on species data and forward selection functions in CANOCO software to identify environmental variables that explained significant amounts of variation $(P \leq 0.10)$ (ter Braak \& Smilauer, 1998). Stepwise RDA is a multivariate technique in the correspondence analysis family, that is similar to stepwise multiple regression in univariate statistics, but RDA incorporates several dependent variables at once. RDA explains variation in a set of response variables (e.g. macroinvertebrate attributes or species) as a function of multiple axes that are combinations of explanatory (environmental) 
variables (ter Braak \& Prentice, 1988). The correlation of an environmental variable with each axis indicates the strength of its relationship with the macroinvertebrate assemblage attributes or species. We ran detrended correspondence analysis on each macroinvertebrate data set to identify the gradient length, or measure of species turnover, and determined that RDA was an appropriate ordination technique (gradient lengths: assemblage attributes $=1.2$, relative abundance $=3.6$ and presence $/$ absence $=2.9) \quad($ ter Braak \& Prentice, 1988). For each RDA analysis, 100 Monte Carlo simulations indicated the statistical significance of the environmental and macroinvertebrate association (ter Braak \& Smilauer, 1998).

Secondly, we quantified the relative influence of the key environmental variables within each spatial scale on macroinvertebrate attributes and species composition. Again we performed RDA on each data pair, but this time we used only the key environmental variables for each environmental and macroinvertebrate variable pair.

Thirdly, we compared the relative influence of environmental variables among multiple spatial scales on macroinvertebrate attributes and species composition. We combined the key environmental variables at the catchment, riparian and reach scales selected in the first step into one environmental data set. Thus, three environmental-macroinvertebrate data set pairs were generated. We then conducted partial RDA procedures to divide the explained variance among the multiple spatial scales for each data pair (Borcard, Legendre \& Drapeau, 1992; Økland \& Eilertsen, 1994). The partial RDAs used all possible combinations of scales as covariates to determine the variance explained for each scale and combination of scales (interactions). The technique yielded the proportion of explained variation for the overall model, each scale, each two-way interaction among the scale pairs and the three-way interaction of all scales.

\section{Results}

\section{Catchment scale characteristics}

The surveyed stream catchment areas ranged from 1 to $458 \mathrm{~km}^{2}$ (Table 3a). Catchment slope, or topographical relief, varied from essentially flat in two wetland catchments to $15.8 \mathrm{~m} \mathrm{~km}^{-1} \quad$ (mean $=3.8 \mathrm{~m} \mathrm{~km}^{-1}$; median $=1.9 \mathrm{~m} \mathrm{~km}^{-1}$ ). Forest was the dominant landcover type in $85 \%$ of the catchments and only four catchments had $<30 \%$ forest. Wetland landcover ranged from 0 to $100 \% ; 24 \%$ of the catchments contained $>0 \%$ wetlands, and wetlands dominated $11 \%$ of the catchments. Open water landcover accounted for $1-5 \%$ at $30 \%$ of the sites, $5-10 \%$ at $4 \%$ of the sites and $10-25 \%$ at $5 \%$ of the sites. Agricultural landcover was $<5 \%$ in $84 \%$ of the catchments. Urbanisation occurred in $10 \%$ of the catchments at low proportions (1-3\%) and only two sites had substantial urbanisation (8 and 18\%). The number of catchments in which various types of surficial geology dominated ranged from coarsetextured glacial till $(17 \%)$, medium-textured glacial till $(13 \%)$, end moraines of medium-textured glacial till $(13 \%)$, glacial outwash sand and gravel $(12 \%)$, lacustrine sand and gravel $(7 \%)$, and end moraines of coarse-textured glacial till $(6 \%)$. The surficial geology types, end moraines of fine-textured glacial till and thin discontinuous glacial till over bedrock, were found in four catchments each, ranging from 13 to $53 \%$, and from 23 to $100 \%$, respectively. Lacustrine clay and silt appeared in four catchments at $<10 \%$, and at four other sites ranging from 27 to $85 \%$. Metamorphic rock comprised $100 \%$ of the bedrock geology in $48 \%$ of the catchments and predominated in $59 \%$ of the catchments. Carbonate comprised $\geq 95 \%$ of the bedrock at $14 \%$, and dominated at $19 \%$ of the catchments. Nine catchments had 100\% sandstone bedrock and it dominated in 19\% of the catchments.

\section{Reach scale habitat characteristics}

The study reaches consisted of varied habitat conditions typically found in shallow to deep streams (Table $3 b$ ). Stream widths ranged from $<2$ to $19 \mathrm{~m}$, with a mean of $7.2 \mathrm{~m}$. Mean thalweg depths ranged from 0.1 to $1.2 \mathrm{~m}$, with a mean of $0.5 \mathrm{~m}$. Stream gradients ranged from 0.3 to $36.9 \mathrm{~m} \mathrm{~km}^{-1}$ for wetland dominated to high-gradient, turbulent sites. Approximately half of the sites had $<10 \%$ silt substrate, and $\sim 40 \%$ of the sites had $>30 \%$ rocky substrate. Half of the sites had $\sim 33 \%$ of their reach-length shaded.

Study reaches also had a wide range of water quality characteristics (Table 3b). Dissolved oxygen ranged from $<5 \mathrm{mg} \mathrm{L}^{-1}$ at 11 low-gradient wetland sites to $>11 \mathrm{mg} \mathrm{L}^{-1}$ at two high-gradient sites. Conductivity varied by nearly an order of magnitude from 56 to $550 \mu \mathrm{S}$. Water turbidity was typically $\sim 5 \mathrm{NTU}$, 
1448

B.M. Weigel et al.

Table 3 Summary statistics of (a) catchment-, (b) reach- and (c) riparian-scale variables significant $(P<0.1)$ in forward selection procedures for redundancy analysis (RDA) of macroinvertebrate assemblage attributes (AA), relative abundance (RA) or presence/ absence (PA) models

\begin{tabular}{|c|c|c|c|c|c|c|c|}
\hline \multirow{2}{*}{$\frac{\text { Variable }}{\text { (a) Catchment scale }}$} & \multicolumn{3}{|c|}{ RDA model } & \multirow[t]{2}{*}{ 25th percentile } & \multirow[t]{2}{*}{ Median } & \multirow[t]{2}{*}{ Mean } & \multirow[t]{2}{*}{ 75th percentile } \\
\hline & & & & & & & \\
\hline \multicolumn{8}{|c|}{ Location, climate and groundwater characteristics } \\
\hline Latitude & AA & RA & PA & 45.6 & 46.3 & 45.2 & 46.7 \\
\hline Longitude & ns & ns & PA & 88.0 & 90.0 & 89.6 & 91.9 \\
\hline Catchment area $\left(\mathrm{km}^{2}\right)$ & ns & RA & PA & 15.3 & 42.4 & 76.9 & 110.2 \\
\hline GDD (degree-day) & AA & ns & ns & 1657 & 1778 & 1792 & 1920 \\
\hline Precip $(\mathrm{mm})$ & $\mathrm{AA}$ & ns & ns & 757.8 & 795.5 & 792.1 & 832.5 \\
\hline DARSITMI $\left(m\right.$ day $\left.^{-1}\right)$ & ns & ns & PA & 0 & 11.6 & 20.5 & 27.6 \\
\hline DARSHDMX $\left(\mathrm{m} \mathrm{day}{ }^{-1}\right)$ & $\mathrm{AA}$ & ns & PA & 3.9 & 13.2 & 19.9 & 29.4 \\
\hline \multicolumn{8}{|l|}{ Landcover proportions } \\
\hline Forest $(\%)$ & AA & RA & PA & 57.4 & 69.8 & 68.0 & 82.3 \\
\hline Grass (\%) & ns & $\mathrm{RA}$ & ns & 0 & 0.8 & 3.6 & 3.9 \\
\hline Open water $(\%)$ & $\mathrm{AA}$ & ns & PA & 0.2 & 0.6 & 2.2 & 2.2 \\
\hline Wetland (\%) & AA & RA & PA & 0 & 0 & 10.2 & 0 \\
\hline \multicolumn{8}{|l|}{ Surficial geology } \\
\hline COSTXGT $(\%)$ & AA & ns & ns & 0 & 0 & 21.3 & 32.0 \\
\hline MEDTXGT (\%) & ns & ns & PA & 0 & 0 & 14.6 & 3.6 \\
\hline ENMFTXT (\%) & $\mathrm{AA}$ & ns & ns & 0 & 0 & 1.2 & 0 \\
\hline LACSNSG (\%) & $\mathrm{AA}$ & $\mathrm{RA}$ & ns & 0 & 0 & 8.3 & 0 \\
\hline LACSNCS $(\%)$ & $\mathrm{AA}$ & $\mathrm{RA}$ & ns & 0 & 0 & 2.7 & 0 \\
\hline TDSGTOB (\%) & AA & ns & ns & 0 & 0 & 2.3 & 0 \\
\hline \multicolumn{8}{|l|}{ Bedrock geology } \\
\hline Metamor (\%) & $\mathrm{AA}$ & $\mathrm{RA}$ & PA & 0 & 86.4 & 57.3 & 100.0 \\
\hline Sandstone $(\%)$ & ns & RA & ns & 0 & 0 & 19.0 & 21.8 \\
\hline \multicolumn{8}{|l|}{ (b) Reach scale } \\
\hline \multicolumn{8}{|l|}{ Channel morphology } \\
\hline Gradient $\left(\mathrm{m} \mathrm{km}^{-1}\right)$ & ns & ns & PA & 0.9 & 1.9 & 4.3 & 4.0 \\
\hline Dist. riff. (m) & ns & ns & PA & 50.0 & 225.0 & 225.9 & 300.0 \\
\hline Mean pool (m) & ns & $\mathrm{RA}$ & ns & 5.0 & 11.7 & 25.2 & 26.0 \\
\hline Depth (m) & ns & $\mathrm{RA}$ & PA & 0.22 & 0.33 & 0.38 & 0.52 \\
\hline Width/depth & ns & $\mathrm{RA}$ & PA & 8.9 & 12.3 & 15.7 & 20.1 \\
\hline Width/depth CV (\%) & ns & ns & PA & 36.4 & 44.0 & 49.7 & 59.7 \\
\hline \multicolumn{8}{|l|}{ Streambed habitat } \\
\hline Silt (\%) & ns & RA & ns & 1.0 & 7.9 & 15.2 & 24.6 \\
\hline Sediment CV (\%) & $\mathrm{AA}$ & ns & ns & 76.9 & 100.3 & 148.8 & 151.2 \\
\hline Algae (\%) & ns & RA & ns & 0 & 0 & 1.0 & 0 \\
\hline Algae freq. (\# station ${ }^{-1}$ ) & ns & RA & ns & 0 & 0 & 2.7 & 0 \\
\hline Macrophytes (\%) & $\mathrm{AA}$ & ns & PA & 0 & 1.6 & 9.5 & 9.8 \\
\hline \multicolumn{8}{|l|}{ Instream and bank habitat } \\
\hline Logs $\left(\# 100 \mathrm{~m}^{-1}\right)$ & $\mathrm{AA}$ & RA & PA & 0.4 & 1.1 & 1.6 & 2.4 \\
\hline Shade $(\%)$ & ns & ns & PA & 12.5 & 31.7 & 33.8 & 51.2 \\
\hline Shade freq. (\# station ${ }^{-1}$ ) & AA & ns & PA & 40.4 & 73.1 & 65.5 & 98.1 \\
\hline Erosion $(\%)$ & ns & ns & PA & 0 & 2.1 & 7.7 & 11.0 \\
\hline \multicolumn{8}{|l|}{ Water condition } \\
\hline $\mathrm{DO}\left(\mathrm{mg} \mathrm{L}^{-1}\right)$ & $\mathrm{AA}$ & $\mathrm{RA}$ & PA & 6.0 & 8.0 & 7.5 & 8.8 \\
\hline Conductivity (umhos) & $\mathrm{AA}$ & RA & PA & 105.7 & 154.1 & 184.0 & 241.0 \\
\hline Alkalinity $\left(\mathrm{mg} \mathrm{L}^{-1}\right)$ & ns & RA & ns & 68.0 & 97.0 & 110.0 & 140.0 \\
\hline Hardness $\left(\mathrm{mg} \mathrm{L}^{-1}\right)$ & ns & RA & ns & 62.0 & 90.0 & 110.7 & 152.0 \\
\hline Turbidity (NTU) & AA & RA & PA & 1.9 & 3.3 & 5.9 & 5.8 \\
\hline
\end{tabular}


Table 3 (Continued)

\begin{tabular}{|c|c|c|c|c|c|c|c|}
\hline Variable & \multicolumn{3}{|c|}{ RDA model } & 25th percentile & Median & Mean & 75th percentile \\
\hline \multicolumn{8}{|l|}{ (c) Riparian scale } \\
\hline \multicolumn{8}{|l|}{ Landcover } \\
\hline Forest $2(\%)$ & $\mathrm{AA}$ & RA & PA & 15.4 & 59.4 & 53.9 & 95.4 \\
\hline Shrub $1(\%)$ & ns & RA & ns & 0 & 14.0 & 25.2 & 38.8 \\
\hline Shrub $2(\%)$ & AA & ns & PA & 0 & 14.0 & 24.0 & 38.8 \\
\hline Meadow $3(\%)$ & AA & ns & ns & 0 & 0 & 5.2 & 5.8 \\
\hline Wetland $1(\%)$ & ns & RA & PA & 0 & 0 & 0 & 0 \\
\hline Undisturbed $1(\%)$ & $\mathrm{AA}$ & RA & ns & 100.0 & 100.0 & 95.3 & 100.0 \\
\hline Developed $1(\%)$ & ns & RA & ns & 0 & 0 & 0.8 & 0 \\
\hline Developed $3(\%)$ & AA & ns & ns & 0 & 0 & 1.9 & 0 \\
\hline Disturbed $1(\%)$ & $\mathrm{AA}$ & ns & ns & 0 & 0 & 3.7 & 0 \\
\hline
\end{tabular}

ns $=$ not significant

but $10 \%$ of the sites exceeded 10 NTU with a high value of 59 NTU. Alkalinity ranged from below detection $\left(<1 \mathrm{mg} \mathrm{L}^{-1}\right)$ to $275 \mathrm{mg} \mathrm{L}^{-1}$, and hardness ranged from 28 to $600 \mathrm{mg} \mathrm{L}^{-1}$.

\section{Riparian scale landcover characteristics}

Riparian areas were mainly forested, shrubs and meadow with relatively little wetland, agricultural or urban lands (Table 3c). Approximately $93 \%$ of the sites had $<10 \%$ disturbed land within any of the three lateral zones $(0-5,0-30,30-100 \mathrm{~m})$. Two sites had $>60 \%$ disturbed landcover within the 0-30 m zone, and three sites had $>60 \%$ disturbed land within the $30-100 \mathrm{~m}$ zone. Forests dominated the riparian areas at $54 \%$ of the sites. Most sites had $<5 \%$ and 13 sites had $>25 \%$ wetland in their riparian zones. Landcover among the three riparian zones correlated strongly $\left(r^{2}=82-94 \%\right)$.

\section{Macroinvertebrate assemblage characteristics}

We found an array of macroinvertebrate assemblages as indicated by the metric summary statistics (Table 2). The macroinvertebrate IBI indicated that $93 \%$ of the sites were in good to excellent condition (Weigel, 2003). MPTV indicated that $61 \%$ of the sites had no apparent organic pollution, and $86 \%$ were in the good to excellent organic pollution range (Hilsenhoff, 1987; Lillie \& Schlesser, 1994). Only $2 \%$ of the sites had $<10$ taxa and $26 \%$ had $<20$ taxa, whereas $23 \%$ had $\geq 30$ taxa. Proportions of EPT individuals indicated $4 \%$ of the sites had poor environmental conditions, whereas the per cent of EPT genera suggested $10 \%$ of the sites had poor conditions.

We identified 160 macroinvertebrate taxa and found 66 taxa that inhabited 10 sites (Table 4).
Chironomidae appeared in every site, and Ephemeropterans were ubiquitous, especially baetid, caenid, heptageniid and leptophlebiid families. Ceratopogonids (Diptera), elmids (Coleoptera), calopterygids (Odonata) and hydropsychids (Trichoptera) occurred in $>50 \%$ of the sites.

\section{Catchment - macroinvertebrate relations}

Catchment variable reduction. The first RDA identified which of the 36-catchment variables were related significantly to the macroinvertebrate variables (Table 3a). The stepwise forward selection procedure used in the first RDA retained 13-catchment variables for the assemblage attribute data set, nine for the relative abundance data set and 10 for the presence/ absence data set. Latitude, and proportions of forest, wetland and metamorphic bedrock were retained for all three macroinvertebrate data sets.

Relations between catchment variables and the three macroinvertebrate data sets. For the assemblage attribute data set, the second RDA on the 13 retained catchment variables explained $53.5 \%$ of the variation $(F=7.07 ; P=0.005)$. The first two RDA axes accounted for $96.7 \%$ of the explained variation $\left(r^{2}=0.517\right)$. On the first RDA axis, values for IBI, EPT, species richness and scrapers were associated positively with per cent forested landcover, precipitation, groundwater delivery rate and to a lesser extent, metamorphic bedrock (Fig. 2a). In the opposite direction on the first RDA axis, proportions of gatherers, midges, amphipods-isopods and predators were positively related to per cent wetland landcover, per cent lacustrine sand and gravel, and growing degree days. 
1450 B.M. Weigel et al.

Table 4 Macroinvertebrate taxa that occurred in $\geq 10$ of the 94 stream sites $(\sim 10 \%)$. Summary statistics were derived from the sites at which the taxon was present. These 66 taxa were used in the RDA of environmental variables with macroinvertebrate relative abundance and presence/absence

\begin{tabular}{|c|c|c|c|c|c|c|}
\hline Taxa & & No. of sites & 25th percentile & Median & Mean & 75th percentile \\
\hline \multicolumn{7}{|l|}{ Amphipoda } \\
\hline Gammaridae & Gammarus sp. & 18 & 7 & 17 & 25.6 & 33 \\
\hline Talitridae & Hyalella sp. & 35 & 4 & 10 & 20.6 & 32 \\
\hline \multicolumn{7}{|l|}{ Coleoptera } \\
\hline \multirow[t]{2}{*}{ Dytiscidae } & Ilybius/Agabus sp. & 13 & 2 & 2 & 4 & 5 \\
\hline & Liodessus sp. & 13 & 1 & 1 & 2.2 & 3 \\
\hline \multirow[t]{4}{*}{ Elmidae } & Dubiraphia sp. & 54 & 2 & 7.5 & 11 & 15 \\
\hline & Macronychus glabratus Say & 10 & 1 & 1 & 1.3 & 1 \\
\hline & Optioservus sp. & 60 & 4 & 15 & 30.5 & 48.5 \\
\hline & Stenelmis sp. & 29 & 2 & 4 & 10.4 & 13 \\
\hline Haliplidae & Haliplus sp. & 14 & 1 & 1.5 & 2.4 & 3 \\
\hline Hydraenidae & Hydraena sp. & 19 & 1 & 2 & 4.9 & 3 \\
\hline \multicolumn{7}{|l|}{ Diptera } \\
\hline Athericidae & Atherix variegata Meigen & 31 & 2 & 3 & 5.1 & 7 \\
\hline \multirow[t]{2}{*}{ Ceratopogonidae } & Bezzia sp. & 25 & 1 & 3 & 4.1 & 4 \\
\hline & Probezzia sp. & 72 & 2 & 4.5 & 8.8 & 11 \\
\hline Chironomidae & & 94 & 75 & 125 & 130.6 & 166 \\
\hline \multirow[t]{2}{*}{ Empididae } & Chelifera sp. & 11 & 1 & 2 & 2.7 & 2 \\
\hline & Hemerodromia sp. & 30 & 1 & 2 & 3.6 & 3 \\
\hline Simuliidae & Simulium sp. & 50 & 1 & 4 & 9.1 & 9 \\
\hline Tabanidae & Chrysops sp. & 32 & 1 & 2.5 & 4.5 & 5 \\
\hline \multirow[t]{4}{*}{ Tipulidae } & Antocha sp. & 25 & 2 & 3 & 4.6 & 6 \\
\hline & Dicranota sp. & 24 & 2 & 3 & 4.5 & 4 \\
\hline & Hexatoma sp. & 35 & 1 & 2 & 2.5 & 3 \\
\hline & Tipula sp. & 21 & 1 & 2 & 2.5 & 3 \\
\hline \multicolumn{7}{|l|}{ Ephemeroptera } \\
\hline \multirow[t]{2}{*}{ Baetidae } & Acerpenna sp. & 20 & 2 & 4 & 7.3 & 12 \\
\hline & Baetis sp. & 65 & 4 & 9 & 13.0 & 18 \\
\hline Baetiscidae & Baetisca sp. & 14 & 1 & 2 & 2.9 & 4 \\
\hline Caenidae & Caenis sp. & 61 & 2 & 7 & 24.4 & 26 \\
\hline \multirow[t]{2}{*}{ Ephemerellidae } & Eurylophella sp. & 35 & 2 & 5 & 9.2 & 9 \\
\hline & Serratella sp. & 15 & 2 & 14 & 11.3 & 19 \\
\hline Ephemeridae & Ephemera sp. & 24 & 1 & 2 & 3.2 & 3.5 \\
\hline \multirow[t]{3}{*}{ Heptageniidae } & Epeorus sp. & 10 & 2 & 4 & 4.4 & 4 \\
\hline & Stenacron sp. & 13 & 2 & 3 & 9.9 & 6 \\
\hline & Stenonema sp. & 60 & 3 & 5 & 8.8 & 11.5 \\
\hline \multirow[t]{2}{*}{ Leptophlebiidae } & Leptophlebia sp. & 42 & 7 & 16 & 27.7 & 34 \\
\hline & Paraleptophlebia sp. & 30 & 5 & 12 & 14 & 19 \\
\hline \multicolumn{7}{|l|}{ Hemiptera } \\
\hline Belostomatidae & Belostoma flumineum Latreille & 16 & 1 & 1 & 1.5 & 1.5 \\
\hline Corixidae & Sigara sp. & 16 & 2 & 3 & 4.3 & 5.5 \\
\hline Pleidae & Neoplea sp. & 11 & 1 & 2 & 2.1 & 2 \\
\hline \multicolumn{7}{|l|}{ Isopoda } \\
\hline Asellidae & Caecidotea sp. & 17 & 2 & 4 & 20.6 & 21 \\
\hline \multicolumn{7}{|l|}{ Megaloptera } \\
\hline Corydalidae & Nigronia serricornis Banks & 27 & 1 & 2 & 2.8 & 3 \\
\hline Sialidae & Sialis sp. & 12 & 1 & 1.5 & 2.2 & 3 \\
\hline \multicolumn{7}{|l|}{ Odonata } \\
\hline Aeshnidae & Boyeria vinosa Say & 25 & 1 & 1 & 1.6 & 2 \\
\hline Calopterygidae & Calopteryx sp. & 50 & 2 & 3.5 & 5.1 & 7 \\
\hline
\end{tabular}


Table 4 (Continued)

\begin{tabular}{|c|c|c|c|c|c|c|}
\hline Taxa & & No. of sites & 25th percentile & Median & Mean & 75th percentile \\
\hline Coenagrionidae & Enallagma complex & 16 & 1.5 & 3.5 & 7.6 & 10 \\
\hline Cordulegastridae & Cordulegaster sp. & 13 & 1 & 3 & 3.9 & 4 \\
\hline Gomphidae & Ophiogomphus sp. & 27 & 2 & 4 & 4.2 & 6 \\
\hline \multicolumn{7}{|l|}{ Plecoptera } \\
\hline Capniidae & & 18 & 3 & 5.5 & 9.6 & 15 \\
\hline Perlidae & Acroneuria sp. & 25 & 2 & 5 & 6.5 & 8 \\
\hline Perlodidae & Isoperla sp. & 18 & 2 & 3.5 & 5.2 & 9 \\
\hline \multicolumn{7}{|l|}{ Trichoptera } \\
\hline Brachycentridae & Brachycentrus sp. & 18 & 3 & 5.5 & 13.4 & 15 \\
\hline Glossosomatidae & Glossosoma sp. & 19 & 2 & 5 & 8.1 & 9 \\
\hline Helicopsychidae & Helicopsyche borealis Hagen & 25 & 1 & 5 & 14.8 & 19 \\
\hline \multirow[t]{3}{*}{ Hydropsychidae } & Ceratopsyche sp. & 47 & 4 & 10 & 14.8 & 19 \\
\hline & Cheumatopsyche sp. & 50 & 3 & 8 & 11 & 13 \\
\hline & Hydropsyche sp. & 24 & 2 & 5 & 6.6 & 11.5 \\
\hline \multirow[t]{2}{*}{ Hydroptilidae } & Hydroptila sp. & 10 & 1 & 4.5 & 4.4 & 6 \\
\hline & Oxyethira sp. & 29 & 2 & 5 & 9.9 & 13 \\
\hline Lepidostomatidae & Lepidostoma sp. & 21 & 2 & 4 & 7.3 & 9 \\
\hline \multirow[t]{2}{*}{ Leptoceridae } & Mystacides sp. & 24 & 1 & 2 & 3.5 & 4 \\
\hline & Oecetis sp. & 21 & 2 & 2 & 3.5 & 4 \\
\hline \multirow[t]{2}{*}{ Limnephilidae } & Hydatophylax argus Harris & 20 & 1 & 3 & 6.2 & 9.5 \\
\hline & Pycnopsyche sp. & 19 & 2 & 2 & 2.6 & 3 \\
\hline \multirow[t]{2}{*}{ Philopotamidae } & Chimarra sp. & 29 & 2 & 4 & 7.3 & 12 \\
\hline & Dolophilodes distinctus Walker & 13 & 2 & 4 & 6.5 & 9 \\
\hline Phryganeidae & Ptilostomis sp. & 14 & 1 & 1 & 2.1 & 2 \\
\hline Polycentropodidae & Polycentropus sp. & 22 & 1 & 2 & 3.6 & 3 \\
\hline Psychomyiidae & Lype diversa Banks & 21 & 2 & 3 & 3.6 & 5 \\
\hline
\end{tabular}

The second RDA axis explained little variance $\left(r^{2}=0.02\right)$ and was most strongly associated with metamorphic bedrock. Variables having low correlation $\left(r^{2} \leq 0.3\right)$ with either of the first two axes were not shown in Fig. 2a, including latitude, open water, end moraines of fine-textured glacial till and coarsetextured glacial till.

For the relative abundance data set, the second RDA on the nine retained catchment variables explained $22.7 \%$ of the variation $(F=2.73 ; P=$ 0.005). The first two axes accounted for $52.6 \%$ of the explained variation $\left(r^{2}=0.119\right)$. On the first RDA axis, the relative abundance of several EPT taxa including Baetis sp., Acroneuria sp., Lepidostoma sp., Glossosoma sp. and Epeorus sp. in addition to labelled taxa in Fig. $2 b$ were positively associated with catchment area and per cent forest landcover. In the opposite direction on the first axis, the relative abundance of Hydraena sp., Neoplea sp. and other taxa typically inhabiting low-flow areas and fine substrates were associated positively with per cent wetland landcover and per cent lacustrine clay and silt. The second RDA axis explained little variance $\left(r^{2}=0.04\right)$ and was most strongly associated with per cent metamorphic bedrock and northerly sites in one direction, and with high per cent lacustrine sand and gravel, and per cent sandstone in the other direction.

For the presence/absence data set, the second RDA on the 10 retained catchment variables explained $21.0 \%$ of the variation $(F=2.21 ; P=0.005)$. The first two axes accounted for $54.0 \%$ of the explained variation $\left(r^{2}=0.114\right)$. As with the RDA of the relative abundance data, EPT and intolerant taxa were associated with per cent forest landcover and catchment area on the first RDA axis, whereas in the opposite direction, taxa tolerant of depositional habitats were associated with per cent wetland landcover (Fig. 2c). The second RDA axis accounted for $4 \%$ of the explained variation and it was associated most strongly with metamorphic bedrock, which was in turn associated with westerly sites (high longitude). 

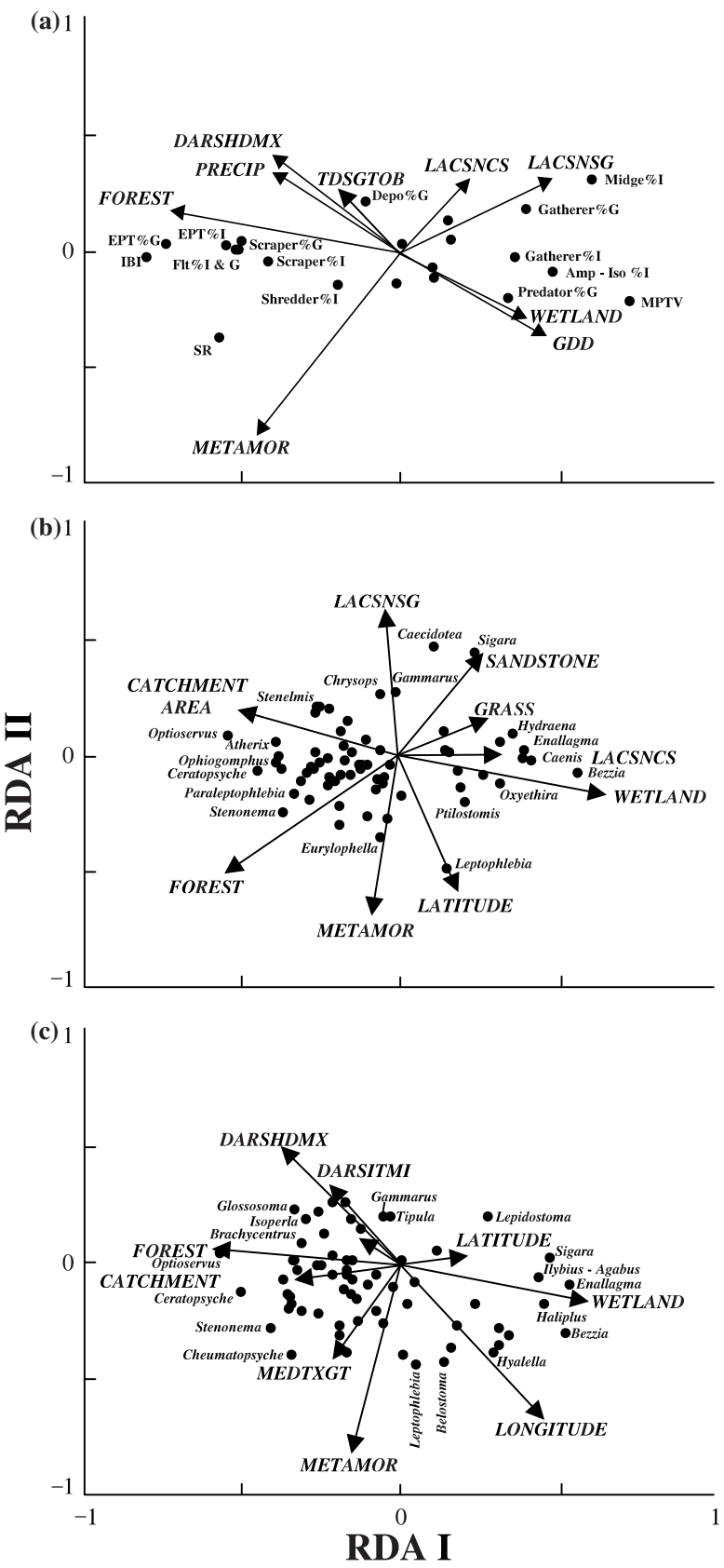

Fig. 2 Plots of the first two axes from redundancy analysis (RDA) of environmental variables at the catchment scale on macroinvertebrate assemblage attributes (a), relative abundance (b) and presence/absence (c). Arrow length corresponds with the importance of the environmental variable and its direction indicates its correlation with the axes. Table 2 has macroinvertebrate assemblage abbreviations and Table 1 has environmental variable abbreviations. Four environmental variables were omitted from the assemblage plot for clarity. The unlabelled arrow in the presence/absence plot represents open water. Taxa commonly used for biomonitoring that responded strongly to ecological gradients were labelled or identified in the text if figure clarity became an issue.

\section{Reach habitat-macroinvertebrate relations}

Reach variable reduction. The first RDA identified which of the 46 reach variables were related significantly to the macroinvertebrate variables (Table $3 b$ ). The stepwise forward selection procedure used in the first RDA retained seven reach variables for the assemblage attribute data set, 12 for the relative abundance data set and 13 for the presence/ absence data set. The number of instream logs, dissolved oxygen, conductivity and turbidity were retained for all three macroinvertebrate data sets. RDA retained channel morphology variables only for the relative abundance and presence/absence analyses.

Relations between reach variables and the three macroinvertebrate data sets. For the assemblage attribute data set, the second RDA on the seven retained reach variables explained $57.2 \%$ of the variation $(F=$ 16.41; $P=0.005)$. The first two axes accounted for $98.3 \%$ of the explained variation $\left(r^{2}=0.562\right)$ with the first axis explaining $95.5 \%$ alone. On the first RDA axis, high biotic integrity represented by IBI, per cent EPT, per cent filterer, per cent scraper and species richness corresponded with dissolved oxygen, shade frequency and number of instream logs (Fig. 3a). In the opposite direction on the first axis, high MPTV and percentages of amphipod-isopods, midges, gatherers and predators were associated with per cent macrophytes, and conductivity and turbidity, which paralleled one another. The second RDA axis explained little variance $\left(r^{2}=0.028\right)$ and mostly showed a gradient from high shade, turbidity and conductivity to high per cent macrophytes.

For the relative abundance data set, the second RDA on the 12 retained reach variables explained $29.1 \%$ of the variation $(F=2.77 ; P=0.005)$. The first two axes accounted for $55.4 \%$ of the explained variation $\left(r^{2}=0.161\right)$. On the first RDA axis, relative abundances of erosional and comparatively intolerant taxa including Glossosoma sp., Ophiogomphus sp., Nigronia serricornis, Helicocopsyche borealis, Chimarra sp. and others labelled in Fig. $3 b$ were associated positively with dissolved oxygen, width/depth and number of instream logs. In the opposite direction on the first axis, taxa inhabiting low-flow areas including Neoplea sp., Hydraena sp., Oxyethira sp., Belostoma flumineum, Leptophlebia sp. and others labelled in 



Fig. 3 Plots of the first two axes from RDA of environmental variables at the reach scale on macroinvertebrate assemblage attributes (a), relative abundance (b) and presence/absence (c). Arrow length corresponds with the importance of the environmental variable and its direction indicates its correlation with the axes. Table 2 has macroinvertebrate assemblage abbreviations and Table 1 has environmental variable abbreviations. In the relative abundance plot, the thick unlabelled arrow represents the algae and algae frequency variables. In the presence/ absence plot, the unlabelled arrow in the positive direction of RDA I represents the mean distance between riffles (Dist. riff.).
Fig. $3 \mathrm{~b}$ were associated with depositional habitat characteristics such as per cent silt substrate, mean length of individual pool habitats, mean depth and turbidity. The second RDA axis explained little variance and was associated most strongly with hardness and width/depth in one direction, and number of instream logs in the other direction.

For the presence/absence data set, the second RDA on the 13 retained reach variables explained $28.1 \%$ of the variation $(F=2.40 ; P=0.005)$. The first two axes accounted for $51.1 \%$ of the explained variation $\left(r^{2}=0.143\right)$. The first axis for presence/absence was similar to the first axis for relative abundance. On the first RDA axis, the presence of Nigronia serricornis, Antocha sp. and taxa labelled in Fig. $3 c$ were associated with high dissolved oxygen, width/depth, shade frequency and number of instream logs. In the opposite direction of the first axis, Enallagma sp., Sigara sp., Hydraena sp., Neoplea sp. and others in Fig. 3c were associated with per cent macrophyte, mean distance between riffles, mean depth and turbidity. Along the second axis, Lype diversa, Isoperla sp., Capniidae and Lepidostoma sp. among others were associated with per cent shade, shade frequency and stream gradient, whereas in the opposite direction, Ophiogomphus sp., Ephemera sp. and others were associated with width/depth, per cent erosion, mean depth and per cent macrophytes. Width/depth CV and conductivity were significant variables in the positive direction of the second axis but were not depicted on Fig. $3 \mathrm{c}$ because of low correlations $\left(r^{2}<0.3\right)$.

\section{Riparian landcover-macroinvertebrate relations}

Riparian variable reduction. The first RDA identified which of the 30 riparian variables were related significantly to the macroinvertebrate variables (Table 3c). The stepwise forward selection procedure used in the first RDA retained six riparian variables for the assemblage attribute data set, five for the relative abundance data set and three for the presence/absence data set. Per cent forest in $0-30 \mathrm{~m}$ riparian zone was the only variable in common for all three macroinvertebrate data sets. Each data set included per cent shrub, but it was important in $0-5-\mathrm{m}$ zone for relative abundance, whereas it was important in $0-30-\mathrm{m}$ zone for assemblage attributes and presence/absence. 
Relations between riparian variables and the three macroinvertebrate data sets. For the assemblage attribute data set, the second RDA on the six retained riparian variables explained $44.4 \%$ of the variation $(F=11.56$; $P=0.005)$. The first two axes accounted for $99.0 \%$ of the explained variation $\left(r^{2}=0.439\right)$ with the first axis explaining $96.1 \%$ alone. On the first RDA axis, biotic integrity as suggested by IBI, per cent EPT, per cent scraper, per cent filterer, and species richness was associated positively with per cent forest and per cent undisturbed landcover (Fig. 4a). In the opposite direction on the first axis, MPTV, and percentages of amphipod-isopods, midges, gatherers and predators corresponded with percentages of meadow, disturbed and developed landcover. The second RDA axis mostly showed a gradient from high per cent shrubs to high per cent developed landcover.

For the relative abundance data set, the second RDA on the five retained riparian variables explained $13.0 \%$ of the variation $(F=2.63 ; P=0.005)$. The first two axes accounted for $76.5 \%$ of the explained variation $\left(r^{2}=0.099\right)$. On the first RDA axis, the relative abundances of Dicranota sp., Glossosoma sp. and Nigronia serricornis among others corresponded to per cent forest (Fig. 4b). In the opposite direction on the first axis, Neoplea sp., Belostoma flumineum, Hydraena sp., Liodessus sp., Ptilostomis sp. and other taxa adapted to depositional habitats were associated with per cent wetland. As with the assemblage attribute analysis, the second RDA axis mostly showed a gradient from high per cent shrubs to high per cent developed landcover. The relative abundance of an isopod, Caecidotea sp., was associated most closely with per cent developed.

For the presence/absence data set, the second RDA on the three retained riparian variables explained $9.5 \%$ of the variation $(F=3.16 ; P=0.005)$. The first two axes accounted for $87.2 \%$ of the explained variation $\left(r^{2}=0.083\right)$. The first axis for presence/absence was similar to the first axis for relative abundance. On the first RDA axis, Helicopsyche borealis, Dolophilodes distinctus, Paraleptophlebia sp., Nigronia serricornis, Brachycentrus sp. and other taxa labelled in Fig. 4c corresponded with percent forest. In the opposite direction of the first axis, Hydraena sp., Liodessus sp., Oxyethira sp., Caecidotea sp., Caenis sp. and others were associated with per cent wetland. Along the second axis, the presence of Pycnopsyche sp., Cheumatopsyche sp., Calopteryx sp., Polycentropus sp., Liodessus sp. and others were associated with per cent shrub.
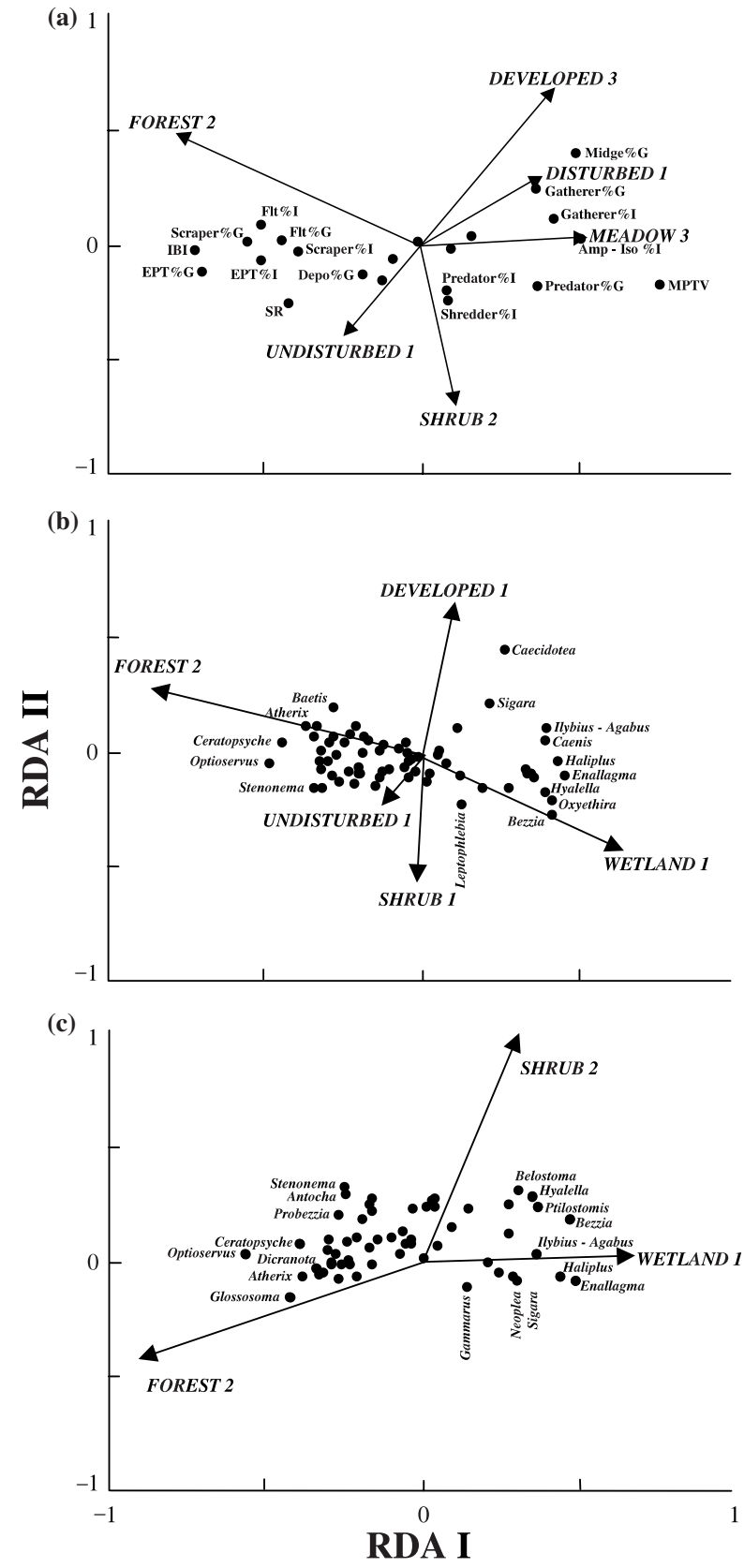

Fig. 4 Plots of the first two axes from RDA of environmental variables at the riparian scale on macroinvertebrate assemblage attributes (a), relative abundance (b) and presence/absence (c). Arrow length corresponds with the importance of the environmental variable and its direction indicates its correlation with the axes. Table 2 has macroinvertebrate assemblage abbreviations and Table 1 has environmental variable abbreviations.

Relations between the combined environmental data and the macroinvertebrate data sets. For the assemblage attributes model, the 26 environmental variables combined across the catchment (13), reach (seven) and riparian 


\section{Assemblage attributes}

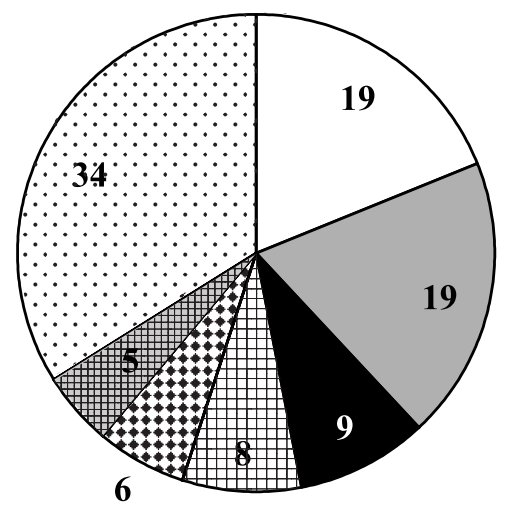

$\square$ Catchment

田 Catchment + Reach
Relative abundance

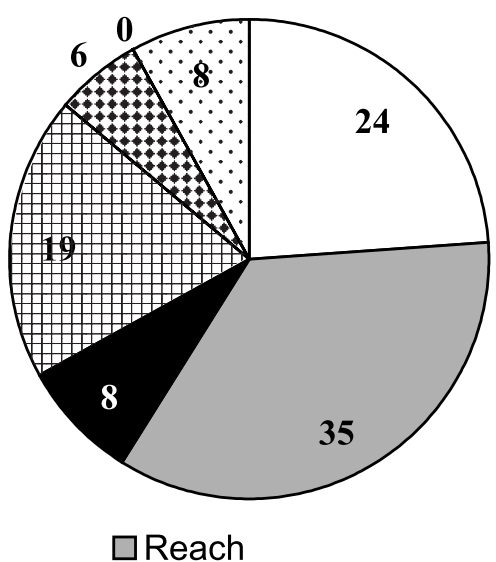

Catchment + Riparian
Presence/absence

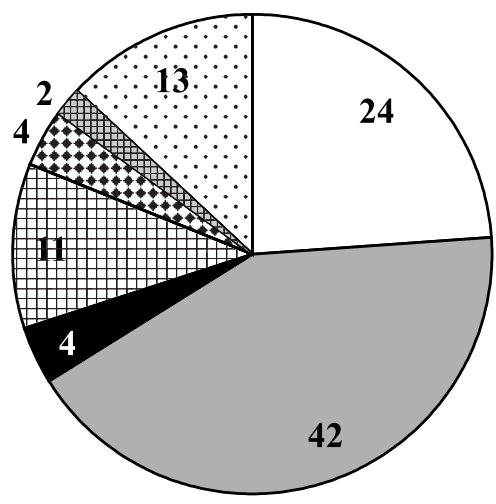

Riparian

Reach + Riparian

$\checkmark$ Catchment + Reach + Riparian

Fig. 5 Partial RDA of environmental variables among multiple spatial scales on macroinvertebrate assemblage attributes, relative abundance and presence/absence. Environmental variables were previously chosen for each spatial scale using RDA forward selection procedures and identified in Figs 2-4. Charts show the proportion of explained variation attributable to environmental variables at different scales and interactions among the scales. The total variance explained was $62.6 \%$ for the assemblage attributes, $48.3 \%$ for relative abundance and $41.1 \%$ for presence/absence.

(six) scales listed in Table 3a-c explained $62.6 \%$ of the variation among sites (Fig. 5). Of the explained variation, $53 \%$ could not be attributed exclusively to variables at one scale, with $34 \%$ of the variation explained by the complex three-way interaction. Catchment and reach scales explained the same amount of variation (19\%), which was double the amount explained by the riparian scale $(9 \%)$.

For the relative abundance model, the 26 environmental variables combined across the catchment (nine), reach (12) and riparian (five) scales listed in Table 3a-c explained $48.3 \%$ of the variation among sites (Fig. 5). The analyses attributed $67 \%$ of the explained variation exclusively to one spatial scale or another. Reach scale variables accounted for more than one third $(35 \%)$ of the explained variation alone, and catchment variables contributed strongly with $24 \%$ of the explained variation. The catchment $\times$ reach interaction was considerable in this model at $19 \%$ (Fig. 5).

For the presence/absence model, the 26 environmental variables combined across the catchment (10), reach (13) and riparian (three) scales listed in Table $3 a-c$ explained $41.1 \%$ of the variation among sites (Fig. 5). Of the explained variation, $70 \%$ was attributable exclusively to variables at the catchment, reach or riparian scale. Again the reach scale accounted for more variation $(42 \%)$ than any other single scale or interaction among scales, and the catchment contribution was $24 \%$. The catchment $\times$ reach interaction at $11 \%$ was important, but the three-way interaction was more influential at $13 \%$.

\section{Discussion}

The assemblage attribute models were inherently less variable than the abundance or presence/absence models because the attribute model incorporated 22 response variables (metrics) that already summarised variation within the assemblage. In contrast, the relative abundance and presence/absence models used 66 individual taxa as response variables. The level of explained variation in each model was substantial considering all possible sources of unexplained variation including different sampling dates, field personnel and random variation (e.g. Hannaford \& Resh, 1995; Richards et al., 1996; Karr \& Chu, 1999). Furthermore, the analyses overlooked some macroinvertebrate life history, behavioural and competitive relationships that may have important effects on 
assemblage composition (Resh \& Rosenberg, 1984; Sweeney, 1993). Despite not accounting for sampling error or complex assemblage interactions, the models attributed substantial amounts of explained variation to each scale.

\section{Catchment environmental effects}

Our results described landcover as more influential than climate or geology, but these variables are intrinsically linked because both growing season duration and soil fertility dictate landcover in the Northern Lakes and Forests ecoregion (Omernik \& Gallant, 1988). In an agricultural region, Richards et al. (1996) determined that geology, or catchment structure, and landcover variables had similar magnitudes of influence on macroinvertebrate assemblages through different habitat-mediated mechanisms. Our study ecoregion is unique in the upper Midwest because its forest and wetland landcover are essentially intact, in contrast to the vast agricultural conversion of most areas. The control of the forest to wetland gradient on macroinvertebrates implied that the macroinvertebrate communities were naturally different in forest-dominated catchments from those in wetland-dominated catchments. Other studies in this region revealed that fish communities differed naturally between wetland and other stream types (e.g. Wang et al., 2003). Collectively, these results indicated that biological expectations should be different for forest and wetland streams.

The forest to wetland gradient appeared to largely define macroinvertebrates along an erosional to depositional habitat continuum, which can be described as a fast- to slow-water habitat gradient (Hawkins et al., 1993). Environmental variables known to correspond with stream flow, including groundwater delivery potentials, precipitation and catchment area, were in the same direction as per cent forest along the first RDA axis. In general, EPT, scrapers and filterers tend to inhabit erosional zones, whereas midges, amphipods, isopods, gatherers and predators tend to inhabit depositional areas (Pennak, 1989; Merritt \& Cummins, 1996). The EPT, scraper and filterer taxa we found (e.g. Optioservus sp., Stenelmis sp., Ceratopsyche sp.) typically conformed to erosional, forested sites, whereas predators and gatherers (e.g. Bezzia sp., Enallagma sp., Caenis sp.) were generally related to wetland-dominated, depositional sites. In our study area, large or forested streams were generally associated with minimal sediment delivery, fast flow, and thus, coarse substrate size favourable for erosional organisms, whereas depositional taxa were generally related to slow flow and fine substrate typical of small or wetland-dominated catchments.

\section{Reach environmental effects}

The influence of reach-scale features on macroinvertebrate composition and abundance has long been recognised in the ecological and biomonitoring literature (e.g. Hynes, 1970; Resh \& Rosenberg, 1984). Separation of aquatic insects based on erosional and depositional habitats provides an all-encompassing framework (e.g. Merritt \& Cummins, 1996). We found that the variables determining macroinvertebrate assemblages were primarily the physicochemical differences between erosional and depositional conditions.

Catchment variables appeared be linked closely to reach variables. The amount of forested landcover is often related to reach habitat quality and woody debris in mid-western streams (Richards and Host, 1994; Wang et al., 1997). Water chemistry also can be linked closely to catchment and riparian landcover (Johnson et al., 1997). Comparison of RDA analyses at both catchment and reach scales suggested that forest-dominated catchments corresponded with high dissolved oxygen, width/depth, number of instream logs and shade (Figs 2 and 3). Sites with high width/depth, or shallow sites, have increased aeration if the substrate is coarse. This greater width/depth may be directly related to high dissolved oxygen levels. In contrast, the channel morphology in wetlands tends to be associated with deeper, slower streams with little aeration, and thus, potentially lower dissolved oxygen levels. The correspondence of wetland sites with conductivity, turbidity, macrophytes, mean pool length and depth, compared with the correspondence of forested sites with high width/depth ratios, supported the concept that macroinvertebrates complied with depositional versus erosional habitats as discussed earlier. Additionally, we recognised the importance of woody debris and canopy shading that helped define the macroinvertebrate-reach habitat continuum and reflected the food source availability (Wallace \& Webster, 1996; Townsend et al., 1997). 
Geological influences were depicted primarily along the second RDA axis, where metamorphic bedrock contrasted sandstone bedrock and lacustrine surficial geology. Richards et al. $(1996,1997)$ found catchment area affected channel shape, whereas surficial geology affected channel substrate. The primary differences in geological types are their affects on channel substrate and groundwater flow, as lacustrine clays are relatively impermeable. Not surprisingly, sites with sandy parent material had sandy substrates whereas those with metamorphic bedrock typically had larger substrates. Similar to our study, Richards et al. (1996) used comparable statistical methods to determine that EPT and erosional taxa were inversely correlated with per cent deep habitats and per cent fine substrate, whereas per cent depositional taxa and per cent predators were positively associated with the same variables.

Other reach habitat variables did not define a major macroinvertebrate-environmental gradient themselves, but rather modified the position of sites along the continuum described. The variables included hardness, alkalinity and stream bank stability, which have been previously shown as important in structuring stream macroinvertebrate assemblages (e.g. Johnson et al., 1997).

\section{Riparian environmental effects}

Apparently, the forest to wetland gradient of riparian landcover influenced stream channel morphology, food supplies and instream habitat. Per cent forest in $0-30-\mathrm{m}$ riparian zone defined the erosional end of an environmental gradient, whereas per cent wetland or per cent disturbed in $0-5 \mathrm{~m}$ zone defined the depositional end. We reason that per cent forest in $0-30-\mathrm{m}$ zone summarised actual landcover influences more effectively than $0-5 \mathrm{~m}$ zone, and that the $30-100 \mathrm{~m}$ zone may not have as direct an influence on stream habitat. Riparian forests are known to stabilise stream banks, reduce erosion, provide habitat, supply organic food sources, filter sediment and nutrients from upland runoff, and moderate stream flow and temperature (reviewed by Lyons, Trimble \& Paine, 2000). Stream segments associated with riparian wetlands are usually low gradient with slow-flow and silt substrate, which are typical habitats for macroinvertebrates adapted to wetland-associated physicochemical characteristics (Mitsch \& Gosselink, 1986).
Undisturbed and developed landcover types became especially important in the riparian zone analyses unlike in the catchment analyses. These landcover types contrasted, mostly along the second RDA axis. Stewart et al. (2001) found that longitudinal fragmentation of the riparian buffers was inversely related to stream biotic integrity and habitat condition. While we did not assess fragmentation of riparian landcover types directly, per cent developed and per cent disturbed landcovers may have been related to the level of fragmentation.

Our results initially seemed to contradict the concept that scrapers are associated with benthic primary production and light availability to streams (Sweeney, 1993; Wallace \& Webster, 1996). We showed that per cent scrapers were correlated with per cent forest landcover at the riparian and catchment scales. However, we noted earlier that the average stream channel had $\sim 66 \%$ open canopy despite having highly forested riparian and catchment landcover, suggesting primary production may not be lightlimited. Weigel et al. (2000) also found per cent scrapers in forested stream reaches to be higher than in open reaches, with forested reaches having greater width/depth (Lyons et al., 2000). We showed that per cent scrapers corresponded to width/depth in this study as well.

\section{Relative influence of reach versus catchment environmental effects}

The catchment scale may operate as a 'filter' that constrains species through selective habitat forces. As Poff (1997) described the hierarchical interaction of scales, large-scale filters are mechanisms that restrict biotic potentials at lower scales. We found that the catchment scale accounted for a substantial amount of the explained variation for each model (19-24\%). After accounting for the influence of catchment-scale variables on the macroinvertebrates, the local reach habitat determined which taxa were present $(42 \%)$ and their relative abundances (35\%). Viewing streams in a hierarchical scale context (Frissell et al., 1986) may explain why substantial amounts of variation were attributed to interactions among spatial scales in the assemblage attribute (53\%), relative abundance $(33 \%)$ and presence/absence (30\%) models. Large-scale filters select against biota 
directly (Poff, 1997), and indirectly by influencing reach-scale features (Richards \& Host 1994; Johnson et al., 1997).

Comparing assemblage attribute plots across scales (Figs $2 \mathrm{a}, 3 \mathrm{a}$ and $4 \mathrm{a}$ ), only subtle changes existed in the attributes' relative position. The response variable consistency among the plots suggested that the environmental variables had similar influences on the macroinvertebrates, and the most influential variables, especially along the first RDA axis, may be related strongly across scales. The same trend held for most taxa in the relative abundance and presence/ absence plots as demonstrated by Optioservus sp., Ceratopsyche sp., Bezzia sp. and Enallagma sp. among others (Figs 2-4). Collectively the analyses showed forested catchments corresponded with instream-dissolved oxygen, log habitats and forested riparian areas, whereas wetland catchments corresponded with instream macrophytes, pool habitats and meadow or wetland riparian areas.

The spatial scale deemed most influential appears to depend upon the range of conditions, predictor variables and response variables of interest (Poff \& Allan, 1995; Lammert \& Allan, 1999). Our analyses showed that the relative influence of scale depended upon whether we characterised macroinvertebrates by assemblage attributes, relative abundance, or presence/absence. We found that the catchment and reach scales influenced the assemblage attributes equally, but the reach scale influenced relative abundance and presence/absence more. Despite using many of the same environmental variables as in our study, Richards et al. (1997) found that macroinvertebrate life history traits were more responsive to the reach scale in a study of agricultural streams. Stewart, Butcher \& Swinford (2000) studied three small tributaries to Lake Michigan and found that reach variables influenced macroinvertebrate structure and function more than catchment variables. Sponseller, Benfield \& Valett (2001) found that macroinvertebrate indices most closely matched riparian landcover within $200 \mathrm{~m}$ upstream of the sampling station. Weigel (2003) explained $77.9 \%$ of the variation among macroinvertebrate assemblage attributes with environmental variables including catchment landcover and local habitat in Wisconsin's Northern Lakes and Forests ecoregion. Approximately half of the explained variation was attributable to catchment landcover, $19.2 \%$ to local habitat and
$29.2 \%$ to the local $\times$ catchment interaction. Study result differences may be attributable to differences in the range of natural environmental conditions, geographical setting and human influences (Allan \& Johnson, 1997).

\section{Conclusions}

Our analyses identified the relative influence of variables within different spatial scales, and the relative influence among multiple spatial scales, on macroinvertebrate assemblages. These results may be more similar to studies of other least-influenced areas as opposed to regions highly modified by agriculture or urban development because most of our randomly selected streams sites in the Northern Lakes and Forests ecoregion were least-influenced. Perhaps our findings are more applicable for stream restoration efforts, suggesting prioritisation of which environmental variables to modify, and setting a target for attaining stream integrity like that in a least-influenced system.

The study suggested that environmental variables at multiple spatial scales had similar influence on macroinvertebrates, and thus, may be related strongly across spatial scales. Relationships across scales were demonstrated by erosional taxa corresponding to forest landcover at the catchment scale, and dissolved oxygen and width/depth at the reach scale. In turn, depositional taxa corresponded to wetland landcover at the catchment scale, and macrophytes and pool habitat at the reach scale. More evidence for scale inter-relatedness surfaced in partial RDA analyses that could not attribute all of the explained variation to variables at one spatial scale or the other. There appeared to be a hierarchical function of scale in which large-scale variables restricted the potential for particular macroinvertebrate traits or taxa to exist at lower spatial scales, and likewise for subsequent spatial scales.

At the catchment scale, we found that per cent forest landcover, catchment size, groundwater delivery potential and precipitation defined the end of an environmental gradient associated with intolerant and erosional macroinvertebrates. We also identified that per cent wetland landcover, number of growing degree days, surficial and bedrock geology and geographical sampling location defined the other end of the environmental gradient associated with 
tolerant and depositional macroinvertebrates. At the reach scale, we found that dissolved oxygen, woody debris, channel morphology, canopy shading and stream gradient formed an environmental gradient direction associated with intolerant and erosional macroinvertebrates. In contrast, macrophytes, silt substrate, water turbidity, conductivity, depth and pool habitat defined the other end of the environmental gradient associated with tolerant and depositional macroinvertebrates. At the riparian scale, per cent forest in $0-30-\mathrm{m}$ zone was linked to relatively intolerant and erosional macroinvertebrates, whereas percentages of wetland, agriculture and urban in 0-5 $\mathrm{m}$ zone, and urban and grass in 30-100 $\mathrm{m}$ zone, were associated with tolerant and depositional macroinvertebrates.

We found that the relative influence of multiple spatial scales depended upon the macroinvertebrate response variable (i.e. assemblage attributes, relative abundance or presence/absence). In comparing studies that defined the relative influence of multiple spatial scales, the results appeared to depend strongly upon the area of interest, site inclusion and the predictor and response variables chosen. Nevertheless, insights into how hierarchical structures affect ecological processes are useful for prioritising management, restoration and policy decisions.

\section{Acknowledgments}

We appreciate the support from U.S. Environmental Protection Agency (U.S. EPA) personnel including John Brazner, Ron Carlson, Naomi Detenbeck, Tim Drexler, Linda Host, Arthur Lubin and Kevin Pierard. We thank Ed Baker, Colleen Elonen, Mike Feist, Paul Kanehl, David Merkey, Scott Niemela, Paul Seelbach, Christopher Smith and Kevin Wehrly for their guidance and field, laboratory and data summarising efforts. This research was funded by U.S. EPA Regional Environmental Monitoring and Assessment Program (Grant R-82620701-2), Michigan Department of Natural Resources (MDNR), Minnesota Pollution Control Agency (MPCA) and Wisconsin Department of Natural Resources (WDNR). We thank the administration and staff at U.S. EPA, MPCA, MDNR and WDNR, especially Ed Emmons, John Lyons, DuWayne Gebken and Mike Staggs of WDNR.

\section{References}

Allan J.D., Erickson D.L. \& Fay J. (1997) The influence of catchment land use on stream integrity across multiple spatial scales. Freshwater Biology, 37, 149-161.

Allan J.D. \& Johnson L.B. (1997) Catchment-scale analysis of aquatic ecosystems. Freshwater Biology, 37, 107-111.

Anderson J.R., Hardy E.E., Roach J.T. \& Witmer R.E. (1976) A land use and land cover classification system for use with remote sensor data. U.S. Geological Survey, Professional paper number 964

Baker M.E., Wiley M.J. \& Seelbach P.W. (2001) GIS-based hydrologic modeling of riparian areas: implications for stream water quality. Journal of the American Water Resources Association, 37, 1615-1628.

Barbour M.T., Gerritsen J., Griffith G.E., Frydenborg R., McCarron E., White J.S. \& Bastian M.L. (1996) A framework for biological criteria for Florida streams using benthic macroinvertebrates. Journal of the North American Benthological Society, 15, 185-211.

Borcard D., Legendre P. \& Drapeau P. (1992) Partialling out the spatial component of ecological variation. Ecology, 73, 1045-1055.

Cummins K.W. (1974) Structure and function of stream ecosystems. BioScience, 24, 631-641.

ESRI (1999) PC ARC/INFO Version 3.2. Environmental System Research Institute, Redlands, CA.

Frissell C.A., Liss W.J., Warren C.E. \& Hurley M.D. (1986) A hierarchical framework for stream habitat classification: viewing streams in a catchment context. Environmental Management, 10, 199-214.

Hannaford M.J. \& Resh V.H. (1995) Variability in macroinvertebrate rapid-bioassessment surveys and habitat assessments in a northern California stream. Journal of the North American Benthological Society, 14, 430-439.

Hawkins C.P., Hogue J.N., Decker L.M. \& Feminella J.W. (1997) Channel morphology, water temperature and assemblage structure of stream insects. Journal of the North American Benthological Society, 16, 728-749.

Hawkins C.P., Kershner J.L., Bisson P.A. et al. (1993) A hierarchical approach to classifying stream habitat features. Fisheries, 18, 3-12.

Hilsenhoff W.L. (1987) An improved biotic index of organic stream pollution. The Great Lakes Entomologist, 20, 31-39.

Hunsaker C.T. \& Levine D.A. (1995) Hierarchical approaches to the study of water quality in rivers. BioScience, 45, 193-203.

Hynes H.B.N. (1970) The Ecology of Running Waters. Liverpool University Press, Liverpool. 
Hynes H.B.N. (1975) Edgardo Baldi Memorial Lecture. The stream and its valley. Verhandlungen der Internationalen Vereinigung für Theoretische und Angewandte Limnologie, 19, 1-15.

Johnson L.B. \& Gage S.H. (1997) Landscape approaches to the analysis of aquatic ecosystems. Freshwater Biology, 37, 113-132.

Johnson L.B., Richards C., Host G.E. \& Arthur J.W. (1997) Landscape influences on water chemistry in Midwestern stream ecosystems. Freshwater Biology, 37, 193-208.

Karr J.R \& Chu E.W. (1999) Restoring Life in Running Waters: Better Biological Monitoring. Island Press, Washington, DC.

Lammert M. \& Allan J.D. (1999) Assessing biotic integrity of streams: effects of scale in measuring the influence of land use/cover and habitat structure on fish and macroinvertebrates. Environmental Management, 23, 257-270.

Lillie R.A. \& Schlesser R.A. (1994) Extracting additional information from biotic index samples. The Great Lakes Entomologist, 27, 129-136.

Lyons J., Trimble S.W. \& Paine L.K. (2000) Grass versus trees: managing riparian areas to benefit streams of central North America. Journal of the American Water Resources Association, 36, 919-930.

Lyons J., Weigel B.M., Paine L.K. \& Undersander D.J. (2000) Influence of intensive rotational grazing on bank erosion, fish habitat quality, and fish communities in southwestern Wisconsin trout streams. Journal of Soil and Water Conservation, 55, 271-276.

Merritt R.W. \& Cummins K.W. (Eds) (1996) An Introduction to the Aquatic Insects of North America, 3rd edn. Kendall/Hunt Publishing Co., Dubuque, IA.

Mitsch W.J. \& Gosselink J.G. (1986) Wetlands. Van Nostrand Reinhold, New York.

Norris R.H. \& Thoms M.C. (1999) What is river health? Freshwater Biology, 41, 197-209.

Økland R.H. \& Eilertsen O. (1994) Canonical correspondence analysis with variation partitioning: some comments and an application. Journal of Vegetation Science, 5, 117-126.

Omernik J.M. \& Gallant A.L. (1988) Ecoregions of the Upper Midwest States. EPA/600/3-88/037, U.S. Environmental Protection Agency, Environmental Research Laboratory, Corvallis, OR.

Overton W.S., White D. \& Stevens D.L., Jr. (1990) Design Report for EMAP, Environmental Monitoring and Assessment Program. EPA 600/3-91/053, U.S. Environmental Protection Agency, Environmental Research Laboratory, Corvallis, OR.

Pennak R.W. (1989) Fresh-Water Invertebrates of the United States: Protozoa to Mollusca, 3rd edn. John Wiley and Sons, New York.
Poff N.L. (1997) Landscape filters and species traits: towards mechanistic understanding and prediction in stream ecology. Journal of the North American Benthological Society, 16, 391-409.

Poff N.L. \& Allan J.D. (1995) Functional organization of stream fish assemblages in relation to hydrological variability. Ecology, 76, 606-627.

Resh V.H. \& Rosenberg D.M. (Eds) (1984) The Ecology of Aquatic Insects. Praeger Publishers, New York.

Richards C., Haro R.J., Johnson L.B. \& Host G.E. (1997) Catchment and reach-scale properties as indicators of macroinvertebrate species traits. Freshwater Biology, 37, 219-230.

Richards C. \& Host G. (1994) Examining land use influences on stream habitats and macroinvertebrates: a GIS approach. Water Resources Bulletin, 30, 729-738.

Richards C., Host G.E. \& Arthur J.W. (1993) Identification of predominant environmental factors structuring stream macroinvertebrate communities within a large agricultural catchment. Freshwater Biology, 29, 285-294.

Richards C., Johnson L.B. \& Host G.E. (1996) Landscapescale influences on stream habitats and biota. Canadian Journal of Fisheries and Aquatic Sciences, 53 (Suppl. 1), 295-311.

Roth N.E., Allan J.D. \& Erickson D.L. (1996) Landscape influences on stream biotic integrity assessed at multiple spatial scales. Landscape Ecology, 11, 141-156.

Simonson T.D., Lyons J. \& Kanehl P.D. (1994) Guidelines for evaluating fish habitat in Wisconsin streams. NC-164, U.S. Forest Service, General Technical Report, St Paul, $\mathrm{MN}$.

Sponseller R.A., Benfield E.F. \& Valett H.M. (2001) Relationships between land use, spatial scale and stream macroinvertebrate communities. Freshwater Biology, 46, 1409-1424.

Stevens D.L., Jr. \& Olsen A.R. (1999) Spatially restricted surveys over time for aquatic resources. Journal of Agricultural, Biological, and Environmental Statistics, 4, 415-428.

Stewart P.M., Butcher J.T. \& Swinford T.O. (2000) Land use, habitat, and water quality effects on macroinvertebrate communities in three catchments of a Lake Michigan associated marsh system. Aquatic Ecosystem Health and Management, 3, 179-189.

Stewart J.S., Wang L., Lyons J., Horwatich J.A \& Bannerman R. (2001) Influences of catchment, riparian-corridor, and reach-scale characteristics on aquatic biota in agricultural catchments. Journal of the American Water Resources Association, 37, 1475-1487.

Sweeney B.W. (1993) Effects of streamside vegetation on macroinvertebrate communities of White Clay Creek in Eastern North America. Proceedings of the Academy of Natural Sciences of Philadelphia, 144, 291-340. 
ter Braak C.J.F. \& Prentice I.C. (1988) A theory of gradient analysis. Advances in Ecological Research, 8, 271-317.

ter Braak C.J.F. \& Smilauer P. (1998) CANOCO Reference Manual and Users Guide to CANOCO for Windows: Software for Canonical Community Ordination (Version 4). Microcomputer Power, Ithaca, New York.

Townsend C.R., Crowl T.A., Arbuckle C.J. \& Scarsbrook M.R. (1997) The relationship between land use and physicochemistry, food resources and macroinvertebrate communities in tributaries of the Taieri River, New Zealand: a hierarchically scaled approach. Freshwater Biology, 37, 177-192.

Vannote R.L., Minshall G.W., Cummins K.W., Sedell J.R. \& Cushing C.W. (1980) The river continuum concept. Canadian Journal of Fisheries and Aquatic Sciences, 37, 130-137.

Wallace J.B., Grubaugh J.W. \& Whiles M.R. (1996) Biotic indices and stream ecosystem processes: results from an experimental study. Ecological Applications, 6, 140151.

Wallace J.B. \& Webster J.R. (1996) The role of macroinvertebrates in stream ecosystem function. Annual Review of Entomology, 41, 115-139.

Wang L., Lyons J., Kanehl P. \& Gatti R. (1997) Influences of catchment land use on habitat quality and biotic integrity in Wisconsin streams. Fisheries, 22, 6-12.
Wang L., Lyons J., Rasmussen P., Seelbach P., Simon T., Wiley M., Kanehl P., Baker E., Niemela S. \& Stewart P. (2003) Catchment, reach, and riparian influences on stream fish assemblages in Northern Lakes and Forest Ecoregion, USA. Canadian Journal of Fisheries and Aquatic Sciences, 60, in press.

Weigel B.M. (2003) Development of stream macroinvertebrate models that predict catchment and local stressors in Wisconsin. Journal of the North American Benthological Society, 22, 123-142.

Weigel B.M., Henne L.J. \& Martinez-R L.M. (2002) Macroinvertebrate-based index of biotic integrity for protection of streams in west-central Mexico. Journal of the North American Benthological Society, 21, 686-700.

Weigel B.M., Lyons J., Paine L.K., Dodson S.I. \& Undersander D.J. (2000) Using stream macroinvertebrates to compare riparian land use practices on cattle farms in southwestern Wisconsin. Journal of Freshwater Ecology, 15, 93-106.

Wiley M.J., Kohler S.L. \& Seelbach P.W. (1997) Reconciling landscape and site based views of aquatic stream communities. Freshwater Biology, 37, 133-148.

(Manuscript accepted 19 March 2003) 